\title{
Virumaa muinasjutud: tõe ja reaalsuse piirimail ${ }^{1}$
}

Risto Järv

\begin{abstract}
Teesid: Eesti Rahvaluule Arhiivi muinasjututekstidest on kümnendik talletatud Virumaalt. Artiklis käsitletakse Virumaal kõige enam levinud muinasjututüüpe: imemuinasjuttudest ATU 300, 301, 313, 327A, 403C, 409, 480, 650B, loomamuinasjuttudest ATU 117, 169*, 243. Virumaale omasteks võib pidada ka mujal Eestis proportsionaalselt vähem tuntud muinasjutte (ATU 312D, 326, 650B). Põhjalikumalt käsitletakse isikunimesid sisaldavaid muinasjutte, mis on muinasjuttude seas üsna erandlikud, ning neid muinasjutte, kus lood on seostatud konkreetse paigaga Virumaal.
\end{abstract}

Märksõnad: kohajutt, muinasjutt, muistend, Virumaa

Muinasjutt räägiks justkui väljamõeldud sündmustest ning seda on jutustatud ennekõike meelelahutuseks. Ometi on muinasjutt seotud reaalse eluga, kõneleb argise elu probleemidest ja katsumustest. Erinevalt kohajuttudest, mis seovad jutu tavaliselt konkreetsete objektidega reaalsel maastikul, on muinasjutud üldistavamad, paigutudes ebamäärasesse aega ja ruumi, millel on siiski äratuntavaid kokkupuutekohti reaalse eluga.

Kõige levinumad muinasjutuliigid on imemuinasjutt (peategelane inimene, kangelasega toimuvad imepärased sündmused) ja loomamuinasjutt (tegelaseks loomad, kelle iseloomujoontes ja käitumises võib leida paralleele inimestega). Oluline erinevus ime- ja loomamuinasjuttude jutustamisel on selles, et imemuinasjutte on varem rääkinud täiskasvanud ning neid on räägitud täiskasvanutele (vrd Holbek 1987; Järv 2005b).

Eesti Rahvaluule Arhiivi muinasjututekste koondavas muinasjuttude andmebaasis olevatest juttudest on laias laastus nii ime- kui loomamuinasjuttudest kümnendik talletatud Virumaalt. Eesti imemuinasjuttude levikukaardi koostamisel selgus, et Virumaa lääne- ja idaserva kihelkonnad kuuluvad selles osas kõige arvukamate piirkondade hulka Eestis, iseäranis tõusevad esile Kadrina ja Haljala kihelkond (vt Järv 2005a: 28-29; EMj I:1 2009: 20-21). 
Ida-Virumaa eriliigilistest rahvajuttudest on põhjaliku ülevaate andnud Kristi Salve. 1992. aastal esmakordselt ilmunud käsitluses on ta sedastanud, et neljale idapoolsele kihelkonnale (Lüganuse, Jõhvi, Vaivara ja Iisaku) on tunnuslik "empiiriliselt hoomatav omapära" (Salve 2013: 131). Just neis neljas kihelkonnas on muinasjuttudes märkimisväärseid sarnasusi meist ida poole jäävate rahvaste muinasjuttudega. Ka Mall Hiiemäe (2006: 428) on ennekõike rõhutanud kihelkondade laenusarnasusi - Virumaa idapoolsete kihelkondade pärimus sarnaneb vadja ja vene omaga, Lääne-Virumaa rannakihelkondade oma aga Soome pärimusega. Kristi Salve peab (Ida-)Virumaa juturohkuse põhjuseks ennekõike piirialade kultuurikontakte ning sellest tulenevat juttude laenamist (Salve 2013: 127). Seda kinnitab asjaolu, et ka muudki muinasjuttuderikkad alad on just piirialad - Mulgimaa ja Setumaa (Järv 2005a: 28-29). Need kolm piirkonda on olnud ka muidu rahvaluule kogumisaktiivsuse tipus Virumaa ja Mulgimaa varasemal perioodil, Setumaa aktiivsem kogumisperiood jääb 20. sajandisse.

Järgnevalt on käsitletud omapärasemaid muinasjutte ja -jututüüpe Virumaa pärimuses. Arvandmete esitamisel on tuginetud korraldustöö senisele seisule - imemuinasjuttude puhul Eesti Kirjandusmuuseumi / Tartu Ülikooli muinasjuttude töörühma tüpoloogiatööle (ilmunud kommenteeritud antoloogiad EMj I:1 2009, EMj I:2 2014), loomamuinasjuttude puhul varasemale tüpoloogiatööle (vt Kippar 1986), mida on muinasjuttude töörühm hiljem täiendanud.

Kui Kristi Salve põhjalikku ülevaatesse Ida-Virumaa juttudest on põimitud näiteid ennekõike Jakob Hurda käsikirjakogust (vt Salve 2013: 129), siis täienduseks seal esitatud ainesele on käesolevas käsitluses toodud näitetekste rohkem Lääne-Virumaa materjali hulgast ning teistest käsikirjakogudest. Arvestades varasemat ülevaadet idapoolsest osast ning Virumaa lääne- ja idaosa mõningast eriilmelisust ei ole püütud eesti muinasjuttude kümnendikku kirjeldades hõlmata tervikuna laia piirkonda, vaid käesolev artikkel tutvustab ka n-ö bukvaalvirumaalisi muinasjutte - pisut enam on tähelepanu pööratud neile muinasjuttudele, kus lugu on seostatud konkreetsete isiku- ja kohanimedega, mis muinasjutužanrile kuigi tavapärane pole.

\section{Muinasjuttude kogujad ja jutuvestmise kontekst}

Muinasjuttude termin viitaks justkui sellele, et need jutud pärinevad vanast ajast. Virumaa puhul kasutatakse üleskirjutustes mitmel korral ka nimetust "vanaviisi jutt" "vanaaigane jutt" - see on siis lugu vanamoodi asjadest. Kuigi Eesti olemasolevad muinasjutuüleskirjutused ongi meieni jõudnud suhteliselt hilisest ajast, pärinevad just Virumaalt, Kadrina pastori Arnold Friedrich 
Johann Knüpfferi kirjapanekutest Eesti muinasjuttude ühed kõige varasemad teadaolevad tekstid (enne 1825. aastat). Tõsi küll, tema on need oletatavasti omakorda saanud Christian Jacob Glanströmilt Järva-Jaani kihelkonnast Järvamaalt (vt lähemalt Toomeos-Orglaan 2005). Need tekstid pole olnud veel sihiteadlikud muinasjututalletused - kirjapanija on käsikirjas sõnu ja korduvaid fraase sageli lühendanud ning osaliselt märkinud vaid sõnade algustähed. Tolleaegsed üleskirjutused olid esmajoones mõeldud keelenäideteks eesti keele tundmaõppimisel ja sõnavara kogumiseks, samasugune oli ka samast ajajärgust pärinev Johann Heinrich Rosenplänteri kogu Pärnumaalt (vt Anderson 1933).

Rahvaluulekogumise kõrgaja, 19. sajandi teise poole Virumaa rahvaluulekogujatest on kõige enam muinasjutte talletanud Alfred Konstantin Kivi - kokku ligi paarsada muinasjuttu, sh 92 imemuinasjuttu. Tema kirjapanekutes on üsna huvitavaid ja eripäraseid arendusi, näiteks jututüübi "Kolm röövitud kuningatütart" lõpus otsustab kangelane selle asemel, et hakata nautima muinasjutule tavalist igavest õnne, teha lihtsalt müügitööd ning hakata elama kaupmehena, pakkudes järjestikku kahes mõisas mõisaprouale esmalt võlukarbi abil riideid, teises mõisas kingi. Viimaks

[...] puuraijuja läinud kolmandasse mõisa. Seal tahetud alt-ilma moodi lossisid. Puuraijuja pannud oma kullast lossi mudelid maha. Need olnud korraga loomulikud suured. Sellesse lossi jäenud nüid puuraijuja ise elama. (E 33032 (3) < Kadrina khk, Hõbeda - Alfred Konstantin Kivi < Aleksander Lehtress, 10 a (1897) [ATU 301].)

Palju on Virumaalt muinasjutte kirja pannud ka Julius Aleksander Rehberg (hiljem Reepärg): üle 40 imemuinasjutu, ning samapalju muid muinasjutuliike. Tema saadetisi on rahvaluulearhiivis nii 19. sajandi lõpust kui ka pärast pikka vaheaega 20. sajandi 30. aastatest. Liitsüžeele jututüüpidest “Täinahk” ja "Vanapagan eksitab õe" (Ee 621 + ATU 312D) lisab ta kommentaari jutuvestja mälu kohta ning rõhutab rahvajuttude kogumise vajadust:

[---] Jutustaja, kes neid lugusid kroonu teenistuses oma seltsimeestelt kuulnud, on kahekümne aasta jooksul mõndagi unustanud. Meelest on tal läinud paljud jutud ja üksikud juhtumised meelde jäänud juttudest. Ka käesolevaski jutus jääb teadmataks, mis sai vanast majast, kus elas üheksa aastat kuninga tütar vanapagana naisena, mis sai rebasest, undist ja karust jne. Kui seda lugu ja teisi, mis siin leiduvad, mitte ennem pole üles kirjutatud, on hea, et niigi palju neist kuuleme. [---] (ERA II 176, 91 (2) $<$ Haljala khk, Kavastu k - Julius Aleksander Reepärg < Aleksander Laks, u 50-a (1937) [Ee 621 + ATU 312D].) 
Järgnevalt toon keskmise arvukusega muinasjutte saatnud kaastöölistelt igaühelt ühe näite. Karl Voldemar Rosenstrauch on muinasjutu "Lohetapja" (ATU 300) süžee alguses maininud, et ta kuulnud seda jutustatavat, kuigi loos on mitmeid ilmseid mõjutusi Kreutzwaldi vastavast arendusest muinasjutus "Õnne rublatükk".

Simuna kihelkonnast, Mõisamaa külast ülesse kirjutatud, ühelt keskealiselt naesterahvalt, kellele ta ema neid noores põlves jutustanud oli.

Koerte Peeter.

Ühel isal oli kolm poega. Kaks poega olid targad, aga üks oli loll. Isa jäi haigeks ja kutsus pojad enne surma enese juurde ja ütles: "Teile kui vanematele ja targematele poegadele jätan ma oma koha, aga lollile pojale annan ma õnne rubla-tüki ja ta võib siis ilmasse minna omale õnne otsima." [---] (EÜS VII, 1951 (165) < Simuna khk - Karl Voldemar Rosenstrauch (1910) [ATU 300].)

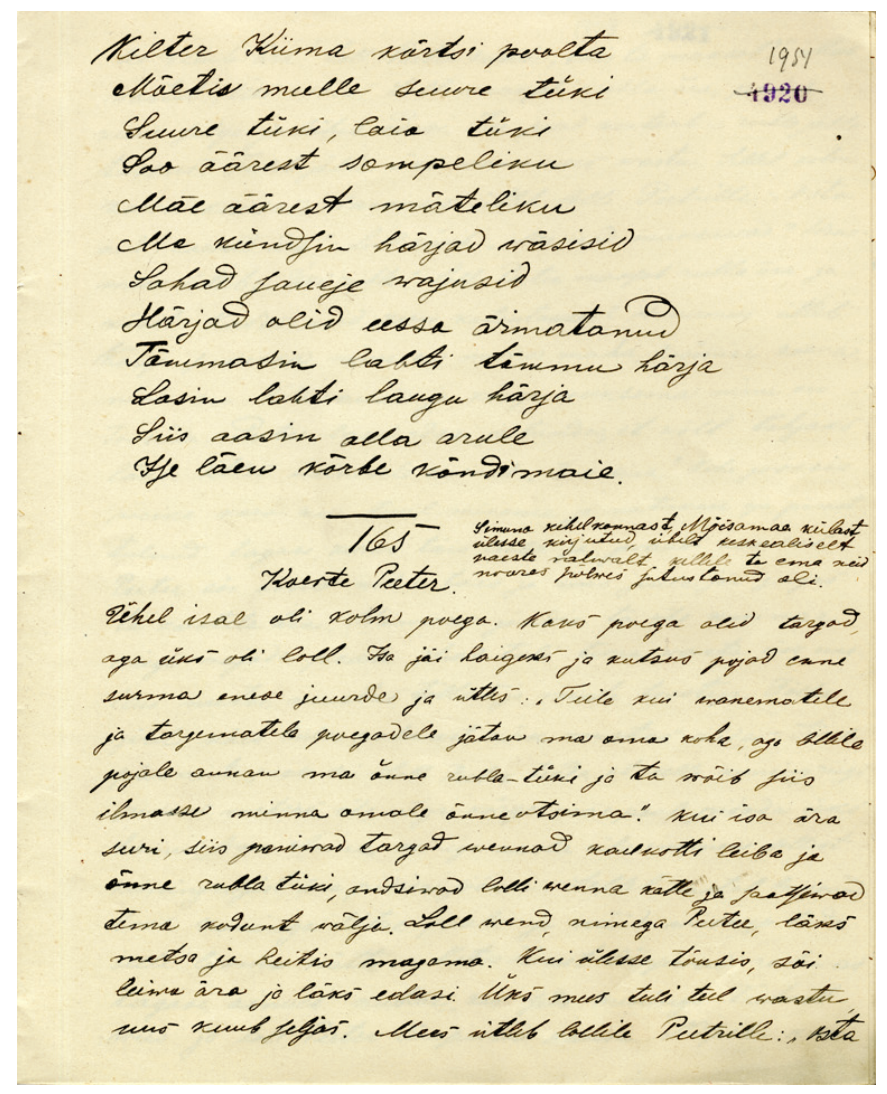

Foto 1. Karl Voldemar Rosenstrauchi kirjapandud muinasjutu algus (EÜS VII, 1951). 
Endel Mets on kirjeldanud videvikuaega kui tavalist talupere ühist ülevalolemise aega, kus räägiti ka vanaaigasid juttusid (= muinasjutte).

Ennevanast käisivad külänaised õhtate külädes näputüad tegemas ja juttu rääkimas. Lüpsäsivad õhtate lehmad vällä ja anti einad ette ja tuld ôli vara üläs võttada ja siis võeti kinnas vai sukk kättä ja mendi siis naabrile ja siis pimedas tuas tehti sukka vai kinnast, ja räägiti juttusid (uudisi, oma mälestusi, nuarepõlve asju ja vanaaigasid juttusid). Kui läks peris pimedast, siis pandi tattnena põlema (väike pudelist tehtud ilma klaasita lamp). "Kes ôli virk, tegi õhtaga kinda vai kapuka valmis."

Käidi äripäivä õhtate ja piaaigu iga õhta. "Ü̈̈ ja vüä, ämärik ja kapukas." Sie õli siis videlikul käimine ja käidi sügise ja talvel, kui ôlivad pimedad ôhtad. Ikke rohkemb käisivad naised. (ERA II 285, 614/5 (3) < Jõhvi khk, Kohtla v, Kohtla k, Metsa t - Endel Mets < Jaan Laur, 60 a (1940).)

Hermann Läntsilt leiab ilmekaid muinasjutukirjapanekuid ka muu ainese seas, näiteks kirjeldab ta oma perenimega seotud pärimust koos muinasjutuga jututüübist “Tuule suund” (ATU 6):

\section{Länts}

Unt saand rebase kinni ja tahand ära süüa. Old läns tuul. Rebane vaatand tuult ja ohkand:

"Ida tuul, kui inge voeti!"

"Läns löh!” käristand unt.

Unt oli aga nii palju ambaid lahti saand, et rebane välja pääsis ja metsa jooksis. (ERA II 153, 243 (36) < Haljala khk - Hermann Länts (1937 (1917)) [ATU 6].)

Üle paarikümne muinasjutu on Virumaalt kirja pannud veel Friedrich Feldbach, Heinrich Masing, Paulus Paurmann, Danel Pruhl, Villem Viirmann, Johannes Schneider, August Tõnurist ning folkloristidest Mall Proodel (Hiiemäe) ja Rudolf Põldmäe.

Muinasjutt on rahvusvaheline rändkaup. Üldistavad lood, mis ei puuduta konkreetseid kohti ja inimesi, on rännanud kergesti üle keelepiiride ja kohanenud olustikuga. Kuna virulastel on olnud palju kontakte venelastega nii piirilinnas Narvas kui ka elanike liikumise tõttu ja kohatise segaasustusega kummalgi pool keelepiiri, leidub Virumaalt mitmeid selliseid üleskirjutusi, kus muidu eestikeelses tekstis on sujuvas tekstivoolus venekeelsed vahelepõiked või laensõnad. Nii võib muinasjutt alata segakeeles: "Vana sõjamees tuli otstavku ja motles, et on sie meie kuningas et mitte tie raha ei anna." Kommentaaris märgibki üleskirjutaja, et jutustaja on "Narva ja Jamburgi vahel elanud, palju raamatuid lugenud, [loo] kuulnud u 30 a eest Luugas Juri käest”. 
Iseäranis hästi tunduvad võõrkeelsed osad säilivat rütmistatud kõnes värssides, nagu näiteks järgmises jutus, kus muidu eesti kirjakeelses jutus on vahevärsid vene keeles:

[---] Tuli vanamees järele, leidis kontisi unnikus. Koer õues aukus:

"Taat tuleb kontisi toob, tede jede, kosti vede!” [taat sõidab, luid veab]

Võerasema akkas koera taplema:

"Auku nii:

"Tede jede, tengi vede!"” [taat sõidab, raha veab]

Tuli taat, tõi ree pial kontisi. (RKM II 380, 345/6 (2) < Kohtla-Järve raj, Iisaku kn, Sälliku k, Sahku t (Iisaku khk) - Alli Vetekaja < Alvine Vetekaja, snd 1893 (1959) [Ee 480E*].)

See jutt on avaldatud ka pealkirjaga "Kelluke hiire kaelas" antoloogias "Eesti muinasjutud" (EMj I:1 2009, nr 157).

Virumaa rahvajuttude pika kogumisajaloo jooksul on samalt inimeselt eri aastatel jutte kirja pannud ka eri kogujad - näiteks on Mari Nirgilt muinasjutte talletatud 1925. aastal ning kuus aastat hiljem. Mõlemal aastal on talt üles kirjutatud variandid imemuinasjutust "Vastaseotsija" (ATU 650B) ning lühemast loomamuinasjutust "Varese naisevõtt" (ATU 243*). Kummaski kirjapanekus torkab silma üsna samalaadne lausejärjestus ja mõningad korduvad tunnussõnad, ent terviku sõnastus erineb märkimisväärselt. Nii näeme, et sõnastuse kujunemisel sõltub palju juhusest. Esitan siinkohal "Vastaseotsija" tüübi algused.

1925:

Olnud vanasti tugev karjane. Härja visanud säuh üle jõe. Hakanud mõtlema; miks minusugune mees karjas käib, parem lähen teisi rammumehi otsima. Läinudki teele. Viimaks leidnud metsa seest suure maja. Suur vanaeit keetnud parajast suppi. Ütelnud karjatsele: "Kuidas sa pojuke siia juhtusid?" See vastanud: "Ega ma olegi pojuke, ma olen tugev rammumees, otsin võitlejaid." - "Heida siis minu poja asemelle puhkama, senni kui pojad koju tulevad," ütelnud eit. [---] (E, StK 31, 72 (19) < Viru-Jaagupi khk, Roela k, Roela vndk - Bernhard Sööt < Mari Nirgi, 68 a (1925) [ATU $650 \mathrm{~B}+$ Aa US 44].)

1931:

Ennemuiste oli üks tugev karjane, viskas kahekümne-puudase ärja üle jõe: säu! Ütles ise: "Mikspärast ma karjas käin, ma olen üks rammumees ja otsin teisi rammumehi, kellega ma võitlen.” Uitas ja uitas ja ükskord leidis: Üks suur vanaeit keedab suure katlaga suppi. Ütleb: "Pojuke, kus 
sa seia oled juhtund?” - "Ma olen üks rammumees, ega ma olegi pojuke, ja otsin, kellega ma võitlen. Kas teil poegi on?”- “Ja, mul on kaks poega, läksid Soomest veskid tooma. Ma nü̈̈d keedan suppi, nad on tulemas. Viska mu poiste asemele pikali." [---] (ERA II 38, 407/8 (13) < Viru-Jaagupi khk, Roela k, Roela vndk - Rudolf Põldmäe < Mari Nirgi, 75 a (1931) [ATU 650B + Aa US 44].)

Mitmeid tähelepanuväärseid arhiivis leiduvaid kirjeldusi jutuvestmise situatsioonidest Virumaal on ära toonud Richard Viidalepp 1965. aastal valminud monograafias "Eesti rahvajuttude laadist, funktsioonist ja jutustajatest". Uurimust piltlikustavad käsikirjade tekstinäited külakarjustest jutustajatena, jutuvestmistest õitsil olles, külakaupmehe juures, videvikku pidades, jäguajal, noorte kooskäimistel, öömaja eest kerjates, muidu kerjates (vt Viidalepp 2004: $20,23,33,45-46,49,52-53,76,78-79)$.

Tavaliselt saame muinasjuttude vestmise olukordade, kommete ja põhjuste kohta käsikirjalistest jututekstidest napilt teada, enamasti algab üleskirjutus juba konkreetse jutu süžeega. Siiski on erandeid. Heaks jutustamisolukorra kirjelduse näiteks on David Timotheuselt 1889. aastal üles kirjutatud lugu, mis leidub ka Pille Kippari kogumikus "Loomad, linnud, putukad" (Kippar 1999a: 38.html). Poiss vastanud teda laulmast keelanud tädile nipsakalt (Sie minu tädi on rumal nagu vana karja krants, et tema uutest kirjadest kedagi ei tia), - see külalistes tähelepanu äratanud vastus ajendas soovi rääkida ära ka sellesisuline muinasjutt. Viidatud olukorda, kus jutustamise tõukeks oli "muinasjutu alusel tekkinud kõnekäänu kasutamine", käsitleb pikemalt Kristi Salve (2013: 150-151).

Just Virumaa ja selle naabruse rannikualadel on tuntud jaguaeg (jäguaeg), mis on traditsiooniline jutuvestmisaeg Kuusalu, Jõelähtme ja Haljala kihelkonna rannakülades, samuti Viru-Nigula, Lüganuse ja Jõhvi kihelkonna rannikualal (Viidalepp 2004: 49-50; Hiiemäe 2010: 11-18); ERk 2017: jaguaeg). Viidalepp (2004: 49) rõhutab, et sellega on käinud kaasas "väga intensiivne rahvajuttude ja mõistatuste harrastus".

Arhiiviandmete põhjal on Virumaa jutuvestjad 19. sajandil olnud pigem mehed - niivõrd, kui kirjapanekud jutustaja sugu kindlaks teha võimaldavad; hiljem, 20. sajandil on jutuvestjateks pigem naised. Samasugune muutus on toimunud ka mujal Eestis, selle taustaks on ilmselt ühelt poolt nii varasemate meeskogujate suurem osakaal kui ka muinasjuttude vestmistendentsi muutumine üldse (vt lähemalt Järv 2001).

"Jutuvestjatest"-kirjameestest on Virumaalt pärit Friedrich Reinhold Kreutzwald, kes eesti muinasjutuainese oma muinasjutukogumikus tuntuks tegi. Kreutzwaldi muinasjutte analüüsinud August Annist (1966: 46) toob välja tema enesekohase kirjelduse: "Olen sündinud Rakvere ligidal keset rikast 
muinaslugude maad..." Kuigi selles Kreutzwaldi lauses on kindlasti üksjagu retoorilist rõhuasetust ning väljaande spetsiifikast tulenevat soovi muinasjutte erilisele kohale tõsta, annab see teisest küljest siiski aimu tema hinnangust jutuvestmiskultuurile. Viidalepa (2004: 26-27) sõnul kirjeldab Kreutzwald just Virumaal Kaarli mõisas saadud kogemuste põhjal jutuvestmist videvikuajal:

Videviku pidamisel, või kui eit ja tütarlapsed õhtul vokkide taga istusid, oli kõige magusam jutuvestmise aeg, ja oh mis kiiresti kadusid seal pikemad talveõhtud meil käest, nii et iga kord ehmatust tegi, kui eit meid magama pidi sundima (Kreutzwald 1953: 6-7).

Kuigi Kreutzwaldi kirjapandud muistendite päritolukohad ongi ennekõike seostatud Virumaaga (Annist 1966: 50), siis muinasjutte on ta haaranud ka omaaegsest muinasjuttude kirjanduslikust traditsioonist, mis Eestisse jõudis saksa kultuuri kaudu ja mille üheks vahendajaks oli muuhulgas ka Kreutzwald ise - vt lähemalt Annist 1966: 362-363).

Kreutzwaldi sõnastatud muinasjututekstid on paljud kas läinud (või tagasi läinud) rahvatraditsiooni ning neid on edasi ümber jutustatud. See on täheldatav ka näiteks Kreutzwaldi muinasjuttude "Põhja konn” ja "Õnne rublatükk" peegelduse puhul jututüübi "Lohetapja” (ATU 300) süžees (vt Järv 1996: 58). Võib tuua näiteid mitmete jututüüpide kohta, mille puhul on Kreutzwald ise rahvapärase motiivi põhjal loonud loo, mis hiljem on saanud rahvatraditsiooni osaks. Näiteks esineb kooliõpetaja ja mõisavalitseja Paulus Paurmanni kirjapanekus Liisu Aruvallalt lugu, mis meenutab Kreutzwaldi muinasjuttu "Puulane ja Tohtlane". Selles lubab "sarviline" sarnaselt Kreutzwaldi jutule kratte tegema läinud mehele: "2 teenrid, need ei taha sinu kääst süüvä ei juuva ei ihu kattet ega jala varju; a tööd teeväd naad suure jõuga, ja teenivad sulle palju raha" $(\mathrm{H}$ II 8, 508 (2) < Jõhvi khk, Päite v ja k < Vaivara khk - Paulus Paurmann < Liisu Aruvald, snd 1891). Kui aga naine vanapaganale hinge jätnud mehe surma järel salvest raha tooma läheb, on lõpp traditsiooniline: "ei õldki muud midägi, kui puhtad leppa lehed ja kase toho raasukesed." Legendiliste muinasjuttude hulka kuuluvas loos ilmuvad ka tegelased Lobi ja Labi ${ }^{3}$ üsna sarnaselt Kreutzwaldi muinasjutuga "Lopi ja Lapi". August Annist nendib selliste juhtumite kohta, et jutuvestjatel on loetud või kuuldud materjal mälus segamini läinud, või on jutte siis kuuldudki tõesti rahvajutuna (Annist 1966: 375).

Samuti on just Virumaalt pärit ainesega seostatud Juhan Kunderi raamatus "Eesti muinasjutud" (Kunder 2008) leiduvaid muinasjutte. See on omakorda üks esimesi kogumikke, kus suur hulk tänapäeval tuntud eesti muinasjuttude süžeid esmakordselt trükis ilmus ja mis omakorda hiljem rahvatraditsiooni mõjutas. Kui Kunderi raamatus ilmunud muistendisüžeedest on mitmed pärit Viljandimaalt (vt Mälk 1963: 255), siis muinasjuttude puhul kirjutab väljaande 
teise trüki eessõnas Matthias Johann Eisen: "Siin [Rakveres] puutus ta Virumaa muinasjuttude vestjatega kokku, keda ta palus enesele mõne loo jutustada" (Kunder 2008: sj.html). Tõsi, ehk on selleski väites omajagu väljaandele tarvilikku kohaga seostatavat autentsusretoorikat.

Seda, et kirjanike looming on ilmselt mõjutanud ka rahvaluulekogujaid, tundub kinnitavat järgmine näide. Kukruselt kirjapandud loo puhul alustab mõisavalitseja Dietrich Timotheus muinasjuttu, kasutades nn aktiivset algust, asudes tavaliste sissejuhatavate jutustavate lausete asemel kohe tegelastevahelise dialoogi juurde. See on teiste muinasjutuüleskirjutuste taustal ebatavaline viis muinasjuttu alustada:

"Mis sa pois vahid siin suu ammuli, nagu tahaksid terve päikese alla nelata," ütles üks kaupmees poe ukse peale astudes, ühe poisile, kes õues ukse ääres seisis.

"Mina olen üks vaene poisike, pole mul isa ega ema, ei sõbra ega sugulast ja hulgun ilma misgi ammetita, kus aga midagi suhu pista saaksin," ütles pois.

“Ma näen et sa üks õiglane pois oled," ütles kaupmees, “kas sa ei taha minu jure poisiks tulla?” [---] (H II 7, 625 (7) < Jõhvi khk, Kukruse Dietrich Timotheus (1889) [ATU 307].)

Samalaadset aktiivset algust on kasutanud muude traditsioonilisemate muinasjutu alustusviiside kõrval ka näiteks setu muinasjuttude kirjapanija Jaan Sandra, ning ilmselt võib seda pidada kirjakultuuri mõjuks.

\section{Imemuinasjutud}

Imemuinasjutud on fiktsionaalsed lood, mis räägivad inimkangelase juhtumustest, kus tegelane puutub kokku millegi imelisega - olgu selleks imelised moondumised, imeesemed, imelised abilised vm. Sageli on jutukangelaseks lihtne vaene poiss või tüdruk, kes loo jooksul leiab õnne. See on kangelane meie keskelt. Sageli vastandub muinasjutukangelane kellelegi, olgu see mõni "koletu jube eläjäs" (Lüganuse khk) või inimkujuline vastane. Enamik Eestis (ja Virumaal) tuntud imemuinasjuttudest on tuntud kogu Euroopas ja sageli kaugemalgi. Eesti populaarsemate jututüüpide seas on Virumaa tekste enamasti $10 \%$ ringis, jäädes enamasti vahemikku 8-12\%. Silmatorkavalt rohkem (üle $25 \%$ ) on Virumaalt muu Eestiga võrreldes talletatud aga tekste, mis kuuluvad jututüüpidesse "Hirmuotsija" (ATU 326), "Vastaseotsija" (ATU 650B), ning iseäranis jututüüpi "Vanapagan eksitab õe" (ATU 312D; 46\%).

Muidugi tuleb arvestada, et vähese materjali kohta on keskmise arvukuse protsendid vähem kõnekad kui suurte andmemassiivide puhul - mistahes 
pärimusteksti jõudmine arhiivi võib olla üsna juhuslik, sõltuvalt sellest, kui palju kuskil leidus entusiastlikke rahvaluulekogujaid, sellest, millise muinasjututundja juurde parajasti külla mindi, millised lood tema repertuaarist parajasti meelde tulid jne. Muinasjututraditsiooni üldtendentsidest annab see siiski teatava pildi, seepärast on ka järgnevalt protsendid esitatud.

Virumaalt kõige enam üles kirjutatud imemuinasjututüüp on "Kolm röövitud kuningatütart” (ATU 301, 30 varianti). See on lugu väga tugevast poisist, kes on mõnikord inimese ja karu poeg, mõnikord lihtsalt nii tugev, et võidab isegi karu ära ning seejärel erinevate seikluste järel päästab kuningatütred. Süžee laiemast populaarsusest annab aimu Johannes Sõsteri pikem kirjapanek "Karu-Ivanist", mille lõpul ta märgib, et on lugu kuulnud mitmelt inimeselt:

[---] Peale eelnimetatud Viru ja Harju rajal mere ääres elavate inimeste kuulsin Karvase Ivani jutte veel 1900 aasta ümber Viru-Nigulas ja nüüd veel hiljuti kolme inimese käest Koeru kihelkonnas Järvamaal. Ükski pärastistest jutustajatest ei ole teadnud minu lapsepõlves saadud teadetele küll midagi uut juure lisada, vaid on vanu teateid aga korranud, sellepärast ei kirjutanud ma mitte iga üksiku jutustaja käest saadud teateid üksikult ülesse, mille juures palju ühte ja sedasama korrata oleks tulnud, vaid liitsin nad ühiseks luguks. [---] (ERM 35, $30<$ Kadrina khk, ViruNigula khk, Koeru khk - Johannes Sõster < Jüri Sõster, Gustav Meikar, Maunus Rotschildt (1911) [ATU 650A + 1159 + 301A].)

Palju üleskirjutusi (29 varianti) on Virumaal jututüübist "Vaeslaps ja peretütar" (ATU 480). Nagu muinasjuttudes ikka, pälvib vaeslaps tegelaste "tulemuspalga", kuna ületab talle pandud ootusi - talle tulevad vastu järjepanu erinevad loomad algul kana, siis lammas, siis lehm. Kõigiga hargneb samalaadne dialoog:

[---] Tulnud varsti lehm vasta, lüpsik sarvis. Lehm üelnud vaeselelapsele: "Lüpsa mind!"

Vaenelaps võtnud lehma sarvilt lüpsiku ja lüpsnud lehma ära. Küsinud siis ise peale lüpsmist: "Kuhu ma selle piima panen, mis ma lüpsin?"

Lehm vasta: "Viska maha, ehk võta omale!"

Aga ei vaenelaps ole piima maha visanud, ega ka omale võtnud. Ta pannud lüpsiku piimaga uueste lehma sarvi. Saatnud siis lehma sinna poole, kust ise tulnud. Ise läinud edasi. [---] (E 34846/7 (10) < Kadrina khk, Hõbeda - Alfred Konstantin Kivi < Jaan E. Einmann, Tõdva-Kõnnu (1897) [ATU 480].)

Võõrastütar seevastu nii ei toimi ning lõpetab halvasti.

Üheks tuntud virumaiseks jututüübiks on muistendlik muinasjutt "Naine libahundiks" (ATU 409, 26 varianti), mis tihti liitub muinasjutuga "Vahetatud 
mõrsja" (ATU 403C, 24 varianti). Selle liitjutu vanim teadaolev üleskirjutus Eestist on samuti seotud Virumaaga, kuigi pärineb hoopis Järvamaalt, nimelt on tegu juba eelpool mainitud Kadrina pastori Knüpfferi vahendusega JärvaJaani pastor Glanströmilt. Jutt pealkirjaga "Ennemuistsed rõugutajad" algab kirjeldusega:

Vaenelaps olnud nende juures kasvatikuks. Nemad hakkand ju inimeseks saama, vaenelaps ja nende oma tütar. Rõõgutaja naene teind siis vaeselapsele uue särgi, oma tütrele jätnud siis vana särgi ja annud temale sü̈̈a. Vaeselapsele pole ühtegi sü̈̈a annud. Tema oma tütar ikka tantsind põrandal, vaenelaps aga nutnud nurgas. [---] (EKÜ, f 232 a1, 360/5 (279) < Kadrina khk < Järva-Jaani khk - Arnold Friedrich Johann Knüpffer, üleskirjutus Christian Jacob Glanströmilt, dateerimata, enne 1825. a [ATU 403C + 409], ilmunud EMj I:1 2009, nr 102).

Selle jutu Eesti variantide põhjalikumas käsitluses on Merili Metsvahi (2010) juhtinud tähelepanu asjaolule, et varaste üleskirjutuste hulgas on Eestis

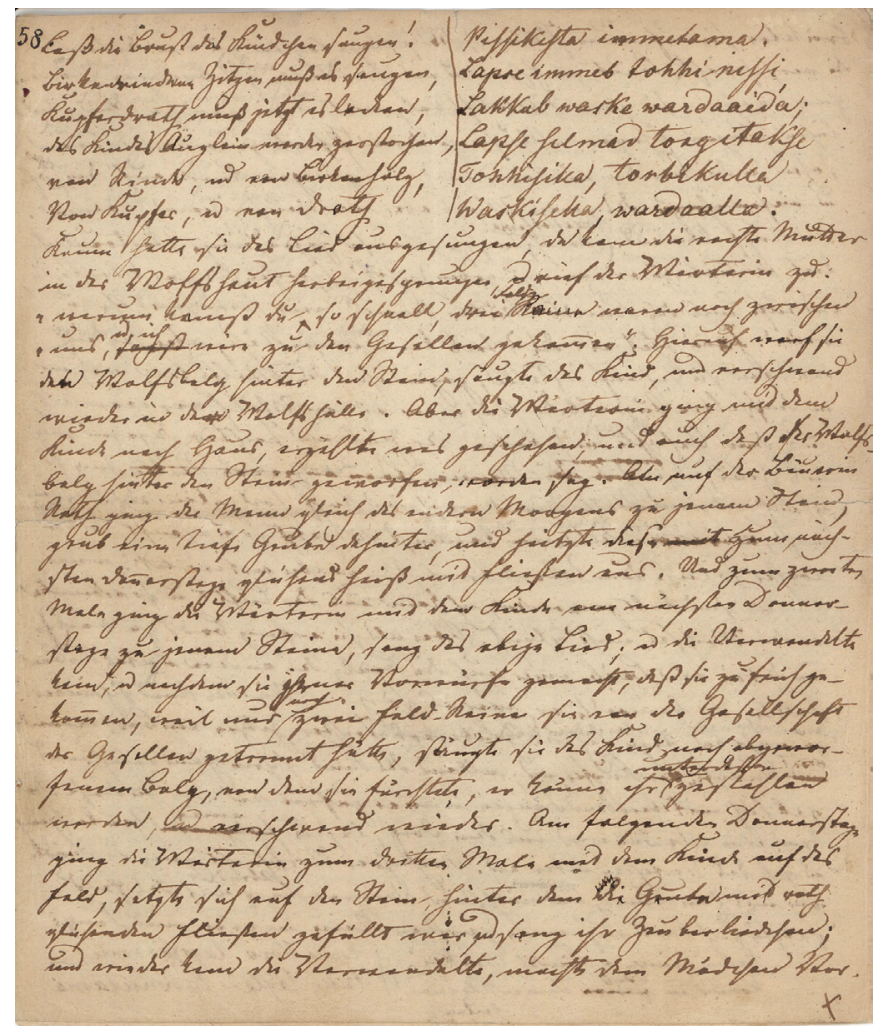

Foto 2. Katke C. H. J. Schlegeli muinasjututõlkest saksa keelde (EKÜ, f 232 d, 58). 
teinegi varane variant, saksakeelne tõlge Christian Hieronymus Justus Schlegelilt (EKÜ, f 232 d, 55/9), ning jääb ebaselgeks, kas Schlegeli variant pärineb 1807. aasta üleskirjutusest Simuna kihelkonnast või siis kuskilt mujalt (Metsvahi 2010: 616). Kui võrrelda üleskirjutuses olevate lauluvärsside sõnavormide ${ }^{4}$ geograafilist levikut eesti regilaulude andmebaasiga, tundub, et Schlegeli üleskirjutust 1807. aastast võiks pidada pigem virumaaliseks - ehk niisiis pärineb see oletatavasti tõesti Simuna kihelkonnast Virumaalt.

Jututüüpi on lähemalt vaadelnud ka Kristi Salve Ida-Virumaa rahvajutte käsitledes. Salve toob välja, et selles piirkonnas ilmneb osas variantidest traditsioonilise hundiks moondumise asemel moondumine ilveseks, sama tegelane muundumise tulemina on omane venelastele ja lätlastele (vt Salve 2013: 133). Just Ida-Virumaa tundub olevat ka selle piirialaks Eestis. Kõrvutamisel LääneVirumaa ainesega selgub, et sellist moondumist esineb seal ainult Viru-Nigula kihelkonnas Lahekülas, kus Hans Lohk on loo üles kirjutanud Narva ja Jamburgi vahel elanud Leenu Uudamilt. ${ }^{5}$ Teises Lääne-Virumaa "ilvese-tekstis" on muinasjutt veelgi omapärasem - tüübile omases vahelaulus esineb ilves, ent edasine tegevus toimub hundiga:

[---] Vana tondi tütar läheb lapsega metsa äärde ja hõiskab: "Nooriku, nooriku, tule lasta lakutama, hilves poega imetama!”

Nü̈̈d tuli naene metsast välja, viskas hundi naha seljast maha, imetas lapse ära, puges hundi naha sisse tagasi ja oligi hunt valmis. [---] (H II 46, 157 (2) < Haljala khk - Julius Aleksander Rehberg < proua Tartu (snd Bergmann) (1893) [ATU 403C + 409].)

Muinasjututüüp "Imeline põgenemine" (ATU 313, 26 varianti) on tihti liitunud teiste jututüüpidega, enamasti lubab metsas äraeksinud mees (deemonlikule) abistajale selle, kes talle esimesena kodus vastu tuleb (mis kodus ta teadmata on), ning peab saatma pärast poisi vanapagana juurde. Poisil aga õnnestub sealt põrgus kohatud neiu abiga põgeneda:

[---] Tüdruk ja pois moondanud ennast aga - tüdruku üheks vanamooriks, poisi aga kepiks tema kätte. Tagaajajad läinuvad aga mööda ja küsinuvad nende käest, et kas nägite siit üht poissi ja tüdrukut mööda minema? Need ütlesid, et nad kedagi hingelist näinud ei ole ja tagaajajad läksivad tagasi.

Nüüd sai eidest ja kepist jälle tüdruk ja pois ja nad rutanuvad edasi. Nü̈̈d saatnud vanamees juba seitse meest välja põgenejaid taga ajama. Tüdruk ja pois muutsivad endid aga tüdruk [originaalis maha tõmmatud: "pois" - R. J.] kirikuks ja pois vahiks sinna juurde. Jällegi küsinuvad tagaaja[ja]d, kas nad ei ole ühte poissi ja tüdrukut siit mööda minema näinud. Muidugi ütles vaht, et ta kedagi mitmel aastal siit pole mööda 
minema näinud. Jällegi läksid tagaajajad tagasi ja pois ja tüdruk ruttasivad edasi.

Nü̈̈d läinud vanamees ise neid taga ajama. Tüdruk muutnud poisi [maha tõmmatud: "enese" - R. J.] järveks, enese [maha tõmmatud: "poisi" - R. J.] aga pardiks. [---] (EÜS VII 2080/1 (305) < Väike-Maarja khk, Porkuni v, Piisupi k - Karl Voldemar Rosenstrauch < Hans Aberthal, 50 a [ATU $313+400+\operatorname{vrd} 325](1910).)^{6}$

Rahvusvaheliselt ülituntud jututüübis "Hans ja Grete" (ATU 327A, 24 varianti) leiavad nõia juurde sattunud vaeslapsed viisi põgenemiseks, Eestile (Virumaale) omaselt joob neid taga ajav vanapagan end lõhki (ATU 1141). Päris paljudele selle tüübi arhiivivariantidele on tunnuslik Juhan Kunderi loos "Vennake ja õeke" esinevate vormelite kasutamine, mida olen lähemalt analüüsinud varem (Järv 2002). Kui toonases käsitluses oli varasem sellist vormelit sisaldav (Eesti) tekst märgitud minu poolt pärinevaks aastast 1893, siis nüüdseks on (Virumaa) korpuses ka 1891. aastat pärinev tekst Haljala kihelkonnast:

[---] Vahe ajal olla kurat juba koju tulnud, läinud tupa, nuusutanud, ise pomisend: "Nuusun, nuusun prae aisu - minu mamma kõrve aisu..." Saanud kohe aru kätte, et linnud ära on lendand, tema "mamma" aga ahju aetud. [---] (H II 38, 61 (2) < Haljala khk - Julius Aleksander Rehberg (1891) [ATU 327A + 1141].)

Vormeliteks on näiteks: "Nuusun, nuusun prae aisu - minu mamma kõrve aisu" (Haljala khk 1891), "Nuusu, nuusu nuumi haisu, oma vanamoori kärsa haisu!" (kaks eri varianti Vaivara khk-s 1893), "nuus nuus nuuma haisu, vanamoori kärse haisu" (Haljala khk 1895).

Nii on tõenäoline, et just see Kunderi versioon on avaldanud suurt mõju hilisemale rahvatraditsioonile (vt Järv 2002: 170-174). Kui on aga tõene Eiseni väide, et ka Kunderi muinasjutud on pärit Virumaalt - ehk ongi siis tegu selle vormeli puhul just virumaalise arendusega?

Muinasjutu "Lohetapja" (ATU 300, 22 varianti) ühes omapärases variandis on peakangelasele antud nimi Muidu, loo algus (koos koerte nimedega) meenutab Kreutzwaldi muinasjuttu "Õnne rublatükk":

\section{Kolm koera.}

Ühe isal olivad kaks poega, üks oli tark, teine rumal. Et rumal üsna muidu vedeles, oli tema nimi Muidu.

Muidu tahtis ükskord teekäigu peale minna ja palus isa käest selle tarvis ühe raha. Sell rahal oli aga see võimus, kui teda kellegille anti, tuli ta varsti andja tasku tagasi. Muidu ostis omale teemoona ja raha tuli jälle tasku. 
Muidu läks metsast läbi ja nägi üht imelikku vanameest, kelle ümber kolm koera lamasid. Vanamees pakkus oma koeri Muidule müia. Muidu ei taht neid ja küsis: "Mis ma nendega, hea kui ise kõhu täie saan."

Vanamees ütles: "See koer, kellel karbike kaelas rippub, toob Sulle süia, tema nimi on Toosüia. Teise koera nimi on Kisulõhki - kui Sa aga tema nime nimetad, kisub ta kõik lõhki, mis Sa tahad. Kolmanda koera nimi on Murramaha - kui Sa tema nime nimetad, murrab ta kõik maha, mis Sa tahad." [---] (H II 12, 492/3 (3) < Väike-Maarja khk - Karl Voldemar Lurich (1890) [ATU 300].)

Muinasjutu "Vastaseotsija" (ATU 650B, 21 varianti) peategelaseks on tugev mees, kes vastaseid otsides kohtub ka müütilise vägimehe Kalevipojaga. Kui Kalevipoeg on pigem tuntud muistenditegelasena ning seostub eelkõige maastikuobjektidega, siis jututüüpi "Vastaseotsija” (ATU 650B) võib pidada muistendite ja muinasjuttude piirimail olevaks. Olgu siinkohal ära toodud üks näide:

Ka rä̈̈givad niisugused, kes seda raamatust ei ole pärandand, kuda poisike metsa ära ekksind, siis ühte majasse saanud, kus teda vana ema kahe poja vahele magama pannud; aga poisside loomulik tuul teda ühe juurest teiise põrutanud. Poiss sialt putkama pannud, metsas teda jälle Kalevipoeg, kellel lauakoorm seljas, leidnud. Sellele kurtnud pois oma lugu, Kalevipoeg pistnud teda oma püksitasku. Kuda siis põrgulised Kalevi poja kallale kippunud; tema neid lappiti laudadega vemmeldanud. Siil põesast õpetanud, et: "Sõrvi lauuda, sõrvi lauuda, Kalevipoeg!” Kuda siis Kalevipoeg võitu saanud, siis oma hia tegijat põesast vällja kutsunud, see aga üelnud, et ta ei julgeda, sest et ta alasti olla. Siis Kalevipoeg kiskunud kasuka õlma küllest tüki ja põesa siilile visand, kes Kalevipoja kasukat tänapäävani kannab. Pärast tulnud Kalevi pojal tasku pandud poiss meele. Kobland kohe kää tasku ja leidnud, et ta vaene surnuks olnud muljutud ägeda võitlemisega. (E 8301/2 (2) < Rakvere khk, Kloodi v, Paatna k - Juhan Lilienbach (1892) [ATU 650B].)

Etioloogilise lõpplahendusega lugu jutustab lisaks Kalevipoja pääsemisele ka sellest, kuidas siil endale kasuka sai ning jutu mõnedes variantides liitub seletus(muistend), kuidas tekkisid kiilaspead - mees pistetud Kalevipoja püksitasku, kus ta pea paljaks hõõrdunud. Tihti on lool õnnetu lõpplahendus, kus peategelane vägimehe hooletu tegutsemise tõttu hoopis surma saab. Vaadates Kalevipoja-muistendite geograafilist levikut ning Virumaa suhtelist domineerimist nende puhul (vt nt HVM I: 591-592), on mõistetavalt ka "Vastaseotsija" muinasjutte kõige rohkem kirja pandud Virumaalt: kogumikus "Muistendeid Kalevipojast" on sellest süžeest Virumaalt 16 varianti ehk 
ligi kolmandik ainesest (52 varianti) (HVM I: 441-457). Süžeed kasutas ka Kreutzwald eeposes "Kalevipoeg” (vt Annist 2005: 164-188).

Kuigi ainult kuue variandiga arhiivi jõudnud, on suhtarvuliselt Eesti kõigist variantidest väga suure protsendiga (46\%) jututüüp "Vanapagan eksitab õe" (ATU 312D), mille üleskirjutused pärinevadki ennekõike vaid Setumaalt ning Virumaa idaosast. Siinkohal on esitatud selle jututüübiga algava liitsüžee tavapärane algusosa:

Ükskord elas üks mies naise ja tütrega. Mies käis metsatüöl. Ükspä ütles mies naisele: "Ära mulle täna lõunet kaasa pane! Las lapsuke tuleb metsa mulle süüa tuoma!”

"Kuda ta sinu juure tulla mõistab? Ta ei leia sind juo üles."

"Küll ta leiab, ma raiun oma tieaaru piale laastud."

Läks mies metsa ja raius oma tieaarule laastud. Tuli vanasaadan, vaatas, mõtles: mis sie on, $\mathrm{mm}$-hh, miks on ühe tie pial laastud? Uot-uot ma raiun oma tie piale $k a$. [---] (RKM II 336, 59/60 (12) < Iisaku, Mäetaguse v, Uhe k - Hilda Jõulmaa, snd $1904<$ Heleene Martin (1976-1978) [ATU $312 \mathrm{D}+\operatorname{vrd} 480+311]$.)

Muu Eestiga võrreldes on Virumaalt proportsionaalselt suur hulk variante (11 varianti, 30\%) üles kirjutatud ka jututüübist "Hirmuotsija" (ATU 326). Selle tüübi variantides ei tunne kangelane millegi ees hirmu, kuni viimaks saab ta kuningatütre naiseks ning hirmu tundma õpetab teda ta oma naine:

[---] Pärast vana kuninga surma saanud ta väimees kuningaks, aga see pole ikkagi veel hirmu tunda saanud, ehk ta küll seda tunda saada südamest igatsenud. Kord ühel öösel, kui kuningas rahuliste maganud, valanud talle proua külme kiisku põue ja - see teinud talle tõeste hirmu. Nü̈̈d olnud ta süda rõõmus, et ta ommeti kord seda kaua igatsetud hirmu tunda saanud ja selle eest oli ta oma prouale tänulik. (H II 38, 222/3 (3) $<$ Haljala - Julius Aleksander Rehberg < Marie Bergmann (1893) [ATU 326].)

Vahemikus 11-20 muinasjuttu on Virumaalt üles kirjutatud veel jutte tüüpidest "Lohetapja" (ATU 300), "Puusärgi valvur" (ATU 307), "Hobune abiliseks" (ATU 314), "Sepp ja kurat” (ATU 330), "Kurat saunas kosimas" (ATU 480A), "Kuningatütar klaasmäel” (ATU 530), “Tänulikud loomad” (ATU 554), "Rikas vend ja vaene vend” (ATU 613) ja “Tugev Mats” (ATU 650A). 


\section{Loomamuinasjutud}

Kui imemuinasjuttudes on oluline kangelase moraalne headus - "paha" saab teenitud "palga", siis loomamuinasjuttudes tundub põhiliseks väärtuseks olevat kavalus ja nutikus. Loomi kujutatakse loomamuinasjuttudes nagu inimesi: nad oskavad rääkida ning on varustatud muude inimlike omadustega. See tingib ka asjaolu, et tavaliselt tegutsevad nad isekeskis, harvemini puutuvad loomad kokku inimeste maailmaga. Loomamuinasjutud on lühikesed ja tihti humoorikad lood, sageli üles ehitatud dialoogile ning neis saab enamasti kaval võitu rumalast. Samas pole "võitja" alati ette teada - kui muidu on eesti loomamuinasjuttudes kavalaim tegelaskuju rebane, siis näiteks 13aastase Paul Schneideri suust kirja pandud loo lõpp näitab, kuidas ka kurg võib olla kavalam rebasest:

[talumees] läheb toob kure haugust välja, paneb haugu kaldale maha ja ise hakkab rebasele teenitud palka kätte maksma.

Mees saanud aga hauku rebase juure, kui ju kurg ülesse tõusnud ja lendu läinud, kisendates: "Minul oli üks ainus mõte."

Aga rebane, kellel tuhat, tuhat mõtet oli, mehe kätte langes ja soojaks kasuka kraeks sai. (E 27277 (4) < Kadrina khk, Tõdva-Kõnnu Joh. Schneider < Paul Schneider, 13 a (1897) [ATU 105 B*], terviktekst ilmunud Kippar 1999: 79.html.)

Arvukalt muinasjutte saatnud Danel Pruhl on kirja pannud loo sellest, kuidas konn tüdrukult kavalalt vabakslaskmise välja kaupleb:

Sügisel palunud konn tüdrukud: "Ole hea tütruk ja pane mind talveks kalja astjase, minul on talvel muidu külm ja paha olla. Kevade õpetan sinule selle eest kolm õpetust."

Tütruk võttis konna ja pani kalja astjase. Kevade võttis tütruk konna astjast välja ja viis järve ääre. Siin õpetas konn: "1) Kui sa hakkad kinga lappima, siis pane nöörile sõlm otsa. 2) Kui lähed sittale, siis pööra nina vastu tuult. 3) Kui hakkad pudru keetma, siis liiguta männaga, aga mitte kulbiga."

Tütruk ei olnud nende õpetustega mitte rahul, vaid lõi konnale keppiga selga, nii et konna selja luu katki läks. Sest ajast saadik on konnal küür seljas. (E 6799 (1) < Haljala khk, Metsiku - Danel Pruhl (1893) [ATU 150].)

Tulenevalt loomamuinasjuttude tegelaspaaridest on jutud tihti dialoogilised ja mõnigikord on loomamuinasjuttude lõpus moraal, mis elu kohta käivaid mõtteid ühel või teisel moel edasi annab.

Tedre ja Vares saanud ükskord medsas kokku (vares elab jo nagu teada, ikke välimaal). Tedre küsinud imetelledes, varekse kääst: "Kuda sina seal 
lagedal korda saad? - eks sinu kallale ka seal inemesed ei kippu! Mina peidan enese alati sügavalle metsa sisse ära, aga siiski odsivad naad mind sealt ülese!”

Vares kostnud uhkeste: "Aa, arvad sa, et se seal õige nali on elada! Peavad aga silmad alati ees ja taga olema."

Se pärast ööltakse tihti: sell olgu alati silmad ees ja taga nõnnagu Vareksel on. (H II 10, 250 (4) < Kadrina khk, Udriku v - J. Nante (1888) [ATU 245].)

Nii nagu Eestis üldiselt, on ka Virumaal loomamuinasjutte talletatud vähem kui imemuinasjutte. Pille Kippari loomamuinasjuttude kataloogi (1986) järgi on Virumaal kõige enam levinud jututüüp "Laps hundipesas" (ATU 169*, Kippari kataloogis 169B* 2; 21 varianti, Eestis tervikuna 23\%). Tüübist on omakorda Virumaal kõige enam variante (6) registreeritud Simuna kihelkonnast ning neis on lugu kolmel korral seostatud erineva konkreetse kohaga - Hirla külaga, Tammiku külaga või siis Mõisamaa külaga.

Hunt viis lapse metsa.

Traksil hunt viind lapse metsa, 3-aastase tütarlapse, kelle nimi olnud Leeni. Hunt viind oma pesasse poegade juure: seitse poega olnud sel hundil. Söögiks hunt tassind sinna "verist ossi” ja laps pidand ka seda sööma.

Kogemata leitud üles. Peetud jahti, leitud kadastikust hundi pesa ja pesast laps. Laps olnud kadund küll, kuid hundi varastamist polnud ju keegi näind.

Hunt ja tema pojad pole lapsele häda teind. Kuid pärast jäänd ta siiski haigeks ja surnud ära. (ERA II 13, 63/4 (51) < Simuna khk, Mõisamaa k - Richard Viidebaum (Viidalepp) < Ann Veelman, 76 a (1929) [Kippar 169B*1-2].)

Samas on hilisemad jutustajad ka selle suhtes kahtlusi avaldanud, küsimustades just seostamist (kauge) kohaga. Nii jutustab jahimees Mihkel Aadva:

Üks laps oli ära kadunud ja ei ole üles leitud teda ja siis olla leitud hundipesast ja siis ei ole rääkindki, teind aga üh-üh. Ja siis pärastpoole ikka õppind rääkima ka jälle ja siis öeld: "Emakuts tõi ikka toorest liha, aga veiked kutsud, need tahid hammustada. Siis emakuts oli tige, keelas ikka, et ei tohi."

Aga see on niisuke jutt. Tema murrab ta ikka maha. Neesukest juttu võib ajada palju. Panevad kuskile võõra maale, et seal. (RKM II 251, 149 (2) < Rakvere, Vetiku k - Mall Proodel (Hiiemäe) < Mihkel Aadva, 80 a (1969) [Kippar 169 B* 1-2].) 
Kui loomajuttude puhul toimub tegevus enamasti metsloomade vahel omakeskis, siis tundub, et Virumaal on iseäranis esindatud ATU tüübikataloogist see alarühm, mis räägib loomade ja inimeste suhtest. Tihtipeale on need lood seotud reaaleluliste juhtumitega - inimeste ja metsloomade kohtumisega ning näiteks hundipessa sattunud loomadega - selgitades ja mõtestades neid juhtumeid traditsioonis tuntud lugude vahendusel. Arvatavasti on selliste lugude populaarsuse üheks põhjuseks olnud ka Virumaa metsarohkus, mis on jätnud oma jälje jutuainesele, ning nii on juttude tegelasteks kodusfääriga seostuvad metsloomad.

Loomamuinasjuttudest on Virumaal arvukuselt järgmine jututüüp "Varese naisevõtt" (ATU 243*, 11 varianti). See muinasjutt sisaldab sageli ka linnuhäälitsuste järeleaimamist ning ligi veerand tekstidest ongi klassifitseeritavad lihtsa loodushäälendina, kus narratiivsust pole (vt Kippar 1985). Mitmetes lugudes on narratiiv välja arendatud väga lühidalt.

Vares ja harakas kahekeste, on leidnud ühe sitke härja liha tükki, vares öölnud, pooleks pooleks. Harakas öölnud, siitsaadik siitsaadik siitsaadik, kiskunudki tükki oma kätte, ja lendnud ära. Vares vaatanud veel järele. (E 11592 < Haljala khk - Danel Pruhl (1894) [ATU 243*].)

Teises loos on aga teksti sisuks ainult dialoog, mis meenutab hoopis puändiga juttu:

Arakas: "Obu on! Obu on!"

Vares: "Kus kaugel? Kus kaugel?"

A.: "Ligi linna! Ligi linna!"

V.: "Kas rasva on? Kas rasua on?"

A.: "Nii kui pekk! Nii kui pekk!"

V.: "Ma tulen kua! Ma tulen kua!"

A.: "Luu ja nahk! Luu ja nahk!"

(E 40196/7 < Jõhvi khk, Kuremäe - J. Lilienbach < Saamuel Hanson, Rakvere (1900) [ATU 243*].)

Arvukuselt kolmas loomamuinasjutt on kataloogi andmetel "Karu härja turjal" (ATU 117, 9 varianti $^{7}$, üle 53\% Eesti variantidest). Selle süžees kannab härg ta turjale hüpanud ning kinni jäänud karu koju. Virumaa variantide puhul on kõnekas, et neist üheksast tekstist kaheksa on seostatud mingi konkreetse kohaga. Muudes Eesti piirkondade variantides esineb küll samuti seostamist, ent Virumaal on see domineeriv.

Muidugi sõltub arhiivi jõudnud lugude arvukus palju juhusest. Kolm selle tüübi lugu on kirja pannud Hermann Läntsi ning need on seostatud Haljala kihelkonna Karula Kuusiku mäega): 
Kuusiku määl old 90 aasta eest suured kuuse kannud, sääl old ennevanast nii suur mets ja karusid täis, et keski sinna ei ole lähend.

Noor karu tuld Kuusiku mäält metsast ja löönd käpa Iilpalu mää rahva ärja laudja päält sisse, aga vana tugev ärg lähend karuga koju mööda tänavat. Küll karu äimand lahtise käpaga ühe tueteiba tagant teise, aga ärg veend karu koju - ei ole mehike enam saand kü̈̈si välja. Keik tee old tue teiba otse täis. Aga õuue sisse mennes saand karu lahtise käpa aida nurga taha ja siis tõmmand ärja rist luist maha. (ERA II 198, 283 (11) < Haljala khk - Hermann Länts (1938 (1917)) [ATU 117].)

Kuigi seda jutusüžeed on Virumaalt talletatud veel, on loomamuinasjuttude kataloogi selle jututüübi variantidest ainsaks paigaga mitteseostatud tekstiks ERA stipendiaadi Mart Tarumi kirjapanek Lüganuse kihelkonnast:

Vanast käisid joa künniärjad ka õitsis. Ühekõrra õli karu üppand künniärjale selga, kü̈̈n jäänd abaluie taha. Tugev ärg õli õld tuld verst maad kodu, karu seljas. Õueveravas vast karu ôli saanud tõise käppa lüia posti ja siis ôli pääsend lahti. (ERA II 125, 386/7 (72) < Lüganuse khk, Maidla v, Tarumaa k-Mart Tarum < Juhan Tarum, 74 a (1936) [ATU 117].)

70. Tamumaal ence wou er oloher. Opetajla kais vand iga aasta vôrra katsurmas a alall ritas. Tonmaa lapsed pridrel Tema tanginad und enipal kooliga.

Sis makr las kothe une nookmafa teha pa sul noolmeister. Suhan Noman ot esmene noolmeister. of aastat un Tanumaa kolrmaita elustati

71. Vauaste mui end nerla tull ses ob seliega pousemst. kugi \& osnand ya knguda kizla.

hel ob sege legemine, the sai uolunsistrist. tana clelnom. omu olr Räisas coolvestmot, see er asxand na enue unputada, pera alles oppris.

72. lawast riaisnd po aimmianiad wa ottor. Vhevorra of rave ippand

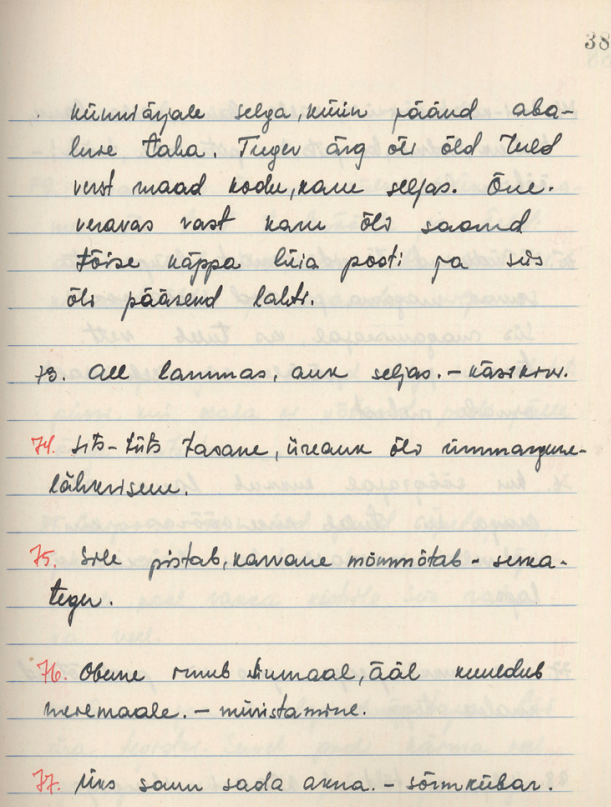

Foto 3. Mart Tarumi kirjapanek Juhan Tarumilt karust härja seljas (ERA II 125, 386/ 7 (72)). 
Virumaalt üleskirjutatud loomamuinasjutud ongi väga palju kohtadega seotud. Eelpool toodud looga "Laps hundipesas" lähedane on Virumaal kolme variandiga tuntud jututüüp "Emakaru imetab inimlast" (ATU 169*, Kippari kataloogis 169B* 3; ATU tüübikataloog on paigutanud kõik erinevad süžeed loomadest, kes inimest ei ründa, jututüübi ATU 169* alla). Ka see pole klassikaline loomamuinasjutt, vaid pigem justkui argielulise põhikoega, ent ometi müütilisevõitu lugu karu pessa sattunud tüdrukust, kellel sünnib karuga laps:

Üks vene naine rääkis mulle seda juttu 1917. a. Jamburis. Jamburi metsades tsaari valitsuse ajal juhtus see lugu. Üks 17-aastane tüdruk läks metsa marjule, Jamburgi lähedale metsa. Karu viis tüdruku oma koopasse. Lesk karu oli ja võttis tüdruku omale naiseks. Enne, kui kinni võttis, nuusutas. Parajasti oli tüdrukul kuuhaigus. Siis ei hakka murdma. Karu hakkas kohe ehtima koobast lehtedega ja aset tegema. Üks kord aastas magas sugutussuhtes. Muidu magas külje juures ja alati jalg tüdruku peal. 7 aastat elas karuga. Aasta pärast oli karuga laps, poeglaps. Pea oli karu pea, aga keha oli inimese keha. Ihu oli sile. Pole rääkind, mõmisend. Naine imetas last ja kasvatas. Talvel karu oli uimane. Naine ise oma tarkusega hoidis toitu talve jaoks. Tuli vähe sü̈̈a. Kui karu vihastas, siis lõi naisele küüned selga ja pigistas vastu ennast. Karu hakkas metsavahi karjast vasikaid ära kandma. Siis metsavaht kutsus ratsajahimehed kokku ja leitigi karu koobas üles. Taheti karu koopasse tulistada, aga naine sai kisendada ja siis ei lastud. Naine pääsis koopast põgenema ja sai ka lapse põngerjala kaasa võtta. Karu lasti maha. Naine käis karu poega laialt näitamas ja sai palju raha. Käis Leningradis ja Moskvas. See vene naine, kes mulle seda rääkis, oli ise ka seda naist ja karu poega näinud. (RKM II 229, 283/4 (3) < Rakvere l < Jamburi - Linda Palu < Salme Salmiste, snd 1897 (1967) [Kippar 169B*3].)

Loomamuinasjuttudest olgu märgitud veel nelja variandiga teada ning mitmes variandis kohaliku paikkonnaga seostatud, Pille Kippari poolt just Eestis eristatud jututüüp "Kellaga karu” (Kippar 179D). Selles jutusüžees annab mees karule juua meest ja viinast segatud jooki ning seob joobnud karule seejärel kella kaela, mille järel on teda hõlpus leida. ATU kataloogis on süžeele viidatud tüübi "Belling the Cat" ("Kassil kell kaelas", ATU 110) juures. Tundub, et rahvusvahelises tüübikataloogis kirjeldatud süžeedes pole tavaliselt tegu ohtliku loomaga ja lõpplahendus pole loo peategelasele fataalne - Virumaa variantides aga leitakse karu hiljem kellahelina järgi ja tapetakse. Pajatusele lähedane lugu on seostatud konkreetsete paikadega - nii olevat see juhtunud näiteks "Ädise mõisa kaeras" või "Rakvere mõisa kaeras". Välistatud pole, et 
siingi on loo levikule kaasa aidanud avaldamine trükisõnas - nagu märgib ka üks jutustajatest. ${ }^{8}$

Samamoodi on seostatud Simuna kihelkonna Imukvere külaga kirjeldus, kuidas poiss läheb puuõõnde, mille veidi hiljem leiab karu:

[---] Karu kes tundis mee lõhna, asund ka selle järele. Asund laskuma alla tagumik eel, aga niikui jõudnud poisini, see krahmand karu sabast kinni ja ise karjatand. See muiduki ehmatas karu, kes kiirelt välja hüpand. Nii pransatand mõlemad maha.

Varsti ajand karjapois end ülese ilma veata, ainult et olnud karu mustusega üleni koos, aga karu lamand surnult ehmatas surnuks. (RKM II 217, 391 < Simuna khk, Salla v - Villem Viirmann < J. Seidel (1966) [Kippar 171C*].)

2004. aastal ilmunud ATU tüübikataloogis on see tüüp paigutatud jututüübiks “Tales about Men and Bears" ("Muinasjutud inimestest ja karudest”, ATU 179*).

Pille Kippar on loomajuttude kataloogis (1986) loomamuinasjuttude ja loomajuttude piirialalt arvesse võtnud mitmeid tüüpe, mis on pajatuslikumad. Kuigi ka Kristi Salve rõhutab õigusega, et see "juhib teiste uurijate tähelepanu kirjeldatud juttudele, innustab neid koguma, osutab rahvusvahelistele suhetele" (Salve 1987: 751), on mõni loomamuinasjuttude kataloogi kuuluv tüüp muinasjutužanri seisukohalt üsna problemaatiline. Näiteks jututüübist "Rebane kaluriks" (Kippar 51B) on Eestist registreeritud üksainus variant, mis pärinebki Virumaalt Kadrina kihelkonnast A. K. Kivi kirjapanekust (ilmunud Kippar 1999: 30.html) ning milles teine tegelane on rebast käsutav lõvi (lõukoer). Uues eesti muinasjuttude tüpoloogias olemegi muinasjuttude töörühmaga otsustanud seda lugu käsitleda pigem individuaalse arendusena, mitte iseseisva, rahva seas tuntud jututüübina. Kuigi folkloorse infovahetuse üheks põhiliseks tunnuseks on olemasolevale pagasile tuginedes uute arenduste loomine ja see näitab traditsiooni elujõulisust, tundub, et vähest esinemust silmas pidades pole põhjust eristada seda jututüüpi omaette Eesti loomamuinasjutu tüübina.

Erandlikke, mitte-eestilisi loomi leidub Virumaa muinasjuttudes siiski veel, ka traditsioonilistes süžeedes. Näiteks tulevad jututüübis "Imeline kukk" ATU 715 kukele järjest vastu erinevad loomad:

[---] Talle tulnud rebane vasta. Rebasele üelnud kukk:

"Rebane, pue mu kõhtu!"

Rebane pugenudki kuke kõhtu. Tulnud hunt vasta. Kukk üelnud:

"Hunt, pue mu kõhtu!"

Hunt pugenudki kuke kõhtu. Tulnud karu vasta. Kukk üelnud:

"Karu, pue mu kõhtu!" 
Karu pugenudki kuke kõhtu. Tulnud elevant vasta. Kukk üelnud:

"Elevant, pue mu kõhtu!"

Elevant pugenudki kuke kõhtu. [---] (E 35382/3 (10) < Kadrina khk, Hõbeda - Alfred Konstantin Kivi (1898) [ATU 715].)

Jutu jätkudes osutub elevant tegelaseks, kes süžeele tunnuslike, kodumaiste loomadega peategelasele appi tuleb. Kui muidu on juttudele tavaks "miljöömorfoloogiline kohanemine" - välise muutmine, tuttavamaks tegemine (vt Kippar 1989: 149), siis ilmselt on selle jutu puhul pidanud kirjapanija tarvilikuks kasutada just anekdoodilikku võõritusefekti.

\section{Teised muinasjutuliigid}

Muudest muinasjutuliikidest, mille korraldustöö on muinasjuttude töörühmal alles pooleli, olgu siinkohal toodud igast liigist üks näide Virumaal populaarsemate tüüpide seast. Legendilistest muinasjuttudest paistab arvukusega silma jutu-tüüp "Kuradile lubatu kirikus" (ATU 810, vähemalt 8 varianti). Kui mees lubab enese teadmata kuradile ära kodus ootava lapse, siis kirikuõpetaja annab nõu, kuidas suureks kasvav poiss pääseks:

[---] "Mine nü̈̈d terveks ööks kiriku, istu altari peale ja hakka lugema, säält kohalt, kus ma näitan. Terve öö pead sa paigal olema ja lugema ja ei tohi enese selja taha vaadata. Teed sa seda, siis oled sa kohe nende käes. Küll nemad meelitavad sind, kuid ära võta nende meelitamist kuulda. Tema tuleb minu näul ka sinu ette, kuid temal on kolm valget lipsu, kuna minul aga kaks on."

Pois läks kiriku. Küll käis öösel vanapagan teda meelitamas, küll kurjaga, küll heaga, aga pois ei kuulanud mitte tema juttu ega vaadanud selja taha. [---] (EÜS IX 1097 (11) < Rakvere khk, Aluvere k - Juhan Elken, Karl Voldemar Rosenstrauch (1912, kirjutatud 1890. a käsikirjast) [ATU 810].)

Novellmuinasjuttudest on Virumaalt vähemalt kümme üleskirjutust jututüübist "Rikka mehe varapärija" (ATU 930), mis mõnedel juhtudel liitub imemuinasjutuga "Kolm karva vanakuradi peast" (ATU 461). Kui tavaliselt ei ole muinasjututegelased ja kohad konkretiseeritud, siis näiteks ühes variandis on pahategelane muidu traditsioonilise kuninga asemel seostatud kohaliku Narva jõe äärse mõisnikuga:

Kord eläs Narva joe ääres üks rikkas moisnik. Tämäl oli üks hüvä kutsar, ükskord sündis moisa prouale tütär, ja kutsari naisele ka sell samal ööl 
sündis poiga. Siis moisa proua ämmämoor ütles, et selle tütrele saab see meheks, kes sell samal ööl on sündind, milla see tütär. Moisnik kuulas sedä asja järele, et kus see poiga on sündind. Aga kui kuulda sai, et see tämä kutsari poiga oli, püüdis tämä sedä kutsari poiga ära tappa, aga ei saand kuidagi moodi, siis käskis moisnik tedä ärä uppudada. [---] (H II 36, 495 (9) < Vaivara khk - Aado Kõrbe (1893?) [ATU 930 + 461].)

Rumala vanapagana muinasjuttudest pajatab huvitavalt pottsepp Gustav Tingas ("ütles, et ta ise selle jutu kõik omast peast on välja mõteld") enesekohase kirjeldusena:

Reisilugu.

Kui mina viel nuar mies olin ja reisimas käisin, sesd ma võiksin pikkad juttud rääkida, mis ma keik nägin ja läbi tegin. Olin Idaindia maal Kalvesdonia linnas. Olin juba linnaga ja tema elamisega tuttav ja läksin ühel suvisel pääval ise oma piad linna ümberkaudu jalutama. Tulin suurde metsa ja uitasin sääl eige lusdi pärasd ümber: sõin pähglaid ja visgasin kiviga oravaid: mis mull viga, ei muret midagi. Aga akkas õhda tulema ja pimedaks menema ja nüüd ma vasd märkasin, et ei osgand koju menna. Aga mull oli nuar julge süda rinnus, mis ma sesd pal'l'u ualisin: tegin tule ülesse, isdusin tule ääre maha ja krõbisdasin oma pähglaid: tuleb uus pääv, eks ma siis lähe linna tagasi. Nõnda ma siis isdun tule ääres ja ei mõtle praegu midagi, sääl tuleb üks irmus elukas, ei ole inimene ei elajas - tühi tiab mis rangudang ta oli vai oli Vanapagan ise - tuleb ja isdub minu vasda tule ääre maha. Mull oli ikke irmu küll nahg täis, kui ta oma koleda silmadega minu otsa vahdis, aga ma lõin südame kõvaks, ei tihed temasd aśśagi, laksutasin aga oma pähglaid edasi. Kuriluom vahib, vahib, mis ma sääl tien ja küsib viimaks: "Mis sa sääl süed, anna mulle kaa!”

Mina pisdan käe tasgu ja annan, aga pahemasd tasgusd kivisid, misga ma oravaid luapisin, olid natuke suuremad, kui lähgri kivid. Mies võttab, paneb ühe suhu ja pureb ja pures ka kivi peeneks et rägises aga. Aga ei se näind taale mekkima ühdigi: sülitas jälle keik suusd väll'a. [---] (H II 53, 219/21 (13) < Haljala khk (Rakvere) - K. Leetberg < Gustav Tingas (1896) [ATU $1061+1060+1115]$.)

Vaatamata nn oma peast kirjeldusele on üsna selgelt esitatud traditsioonilised motiivid. Edasi läheb jutt nii, nagu neis vanapaganalugudes ikka - mees pakub Vanapaganale süüa pähklite asemel kõvu kive, seejärel petab teda kivist vee pigistamisega, petab pererahvast, tehes voodi peale enda asemele "nuku", ja jääb ellu. Lugu lõppeb humoorika selgitusega, miks ta oma vanapaganalt petetud suurest hulgast rahast seppade tõttu ilma jäi. Richard Viidalepp (2004: 111) on 
Eesti eri piirkondades esinevat jutustamist esimeses isikus ehk egomorfistlikke jutte käsitledes välja toonud, et selline viis "teeb asja tavalisest põnevamaks ning lisab sageli humoristlikkust" - mis selle loo puhul peab hästi paika. Tingase muinasjutt "Reisilugu" lõpeb humoristlikult: "Aga pahemb jalg on praegu viel aige." (H II 53, 228). ${ }^{9}$

Kui jutuvestja enam ei jaksanud muinasjutte rääkida, siis aitas hädast välja ka Virumaal vormelmuinasjutt jututüübist "Ilma lõputa jutt” (ATU 2275), nagu näiteks:

Musta härja jutt on kõige pikem jutt, kas tahad ma räägin? (Kui teine ütleb, et tahab, siis korrutakse seda sama nii kaua kuni ta viimaks ära tüdineb ja ütleb, et ei taha, siis ütleb esimene et, noh kui ei taha siis ma ei räägi). (A 3014 (3) < Väike-Maarja khk, Vao v, Vao k - Herman Veisberg (1922) [ATU 2275].)

Kui seda narritamisjuttu on pigem peetud ennekõike setu jututüübiks (vrd Viidalepp 2004: 92-94), siis ilmselt on sellegi süžee jõudmisel ka Virumaale rolli mänginud slaavi jututraditsiooni mõju ja naabrisuhted.

\section{Nimedest ja reaalsusest Virumaa muinasjuttudes}

Olgugi, et muinasjutud kirjeldavad inimese hakkamasaamist väljamõeldud maailmades, on neis ometi tõmmatud järjepidevalt seoseid ka reaalse eluga muinasjutužanr ei kaugene päris fantastikasse, vaid seal on küllaltki palju realistlikku. Üheks selliseks elemendiks on muinasjututegelaste ja muinasjutukohtade nimed.

Ida-Virumaa rahvajuttudest 1992. aastal ülevaadet andes on Kristi Salve sedastanud, et kui Eesti traditsioonis kehtib tegelaste mittenimetamise põhimõte eriti järjekindlalt, siis "teistest rahvastest mõnedel, näiteks venelastel, kohtab pärisnimesid suhteliselt sagedasti. Üksikutel juhtudel esineb nimelisi tegelasi ka Ida-Virumaa muinasjuttudes ja enamasti osutavad nad jutu idapoolsetele allikatele" (Salve 2013: 132-133).

Sageli ongi muinasjutukangelane nimeta. Kuna muinasjutukangelane on üldistus, "üks meie seast”, kannab ta muinasjutus nagu Eestis üldiselt, nii ka Virumaal tavaliselt traditsioonilist nime - meeskangelaste puhul on kasutatud nimesid nagu nt Jaan, Ants (Hans) ja Jüri, naiskangelase puhul näiteks Ann või Mari (vt ka Järv 2005c). Kuna Virumaa asub ida ja lääne jututraditsiooni piiril, on huvitav vaadelda, milliseid nimesid, mis kontekstis ning asjaoludel esineb Virumaa muinasjuttudes. Seejuures ei pärine Virumaa muinasjuttude 
vene nimed sugugi ainult idapoolselt Virumaalt - nii näiteks esineb Haljala kihelkonnas üleskirjutatud muinasjutus kassi pojast kangelane nimega Jiwan Kośskin [< 'Ivan Kassipoeg'] ning Väike-Maarja kihelkonnas Karupoeg Ivan, seevastu Ida-Virumaal esinevad näiteks Hans (Jõhvi khk) või Ants (Jõhvi khk).

Mitmetest tekstidest leiame kinnitust sellele, et nime kasutamine pole muinasjutuvestjale kuigi oluline, seda hakatakse kasutama alles juttu kellelegi konkretiseerides, tähelepanu kellelegi teravdades. Näiteks lugu, kus pika muinasjutu jooksul räägitakse lihtsalt tüdrukust, ent loo lõpus küsib taas koju jõudnud, seni nimeta tütarlaps oma vanematelt: "Ae, kas teie siis mind ei tunne. Mina jo teie Lieni."10 Teises, kolme vennaga loos küsib isa kolmelt (nimeta) vennalt nende nimesid, ning mainib kolmanda, peategelasena isikustatud venna nime, ent teeb seda samuti nagu muuseas:

\section{[---] "Mis tee olete õppinud?"}

Vanem poeg vastu "Mina õppisin küttiks."

Teine jälle. "Mina õppisin kiigrimeheks.” [kiikrimeheks - R. J.]

Kolmas jälle. "Mina õppisin vargaks."

Kõige noorem poeg Hans, aga õppinud rättseppaks. [---] (E $6521<\mathrm{Hal-}$ jala khk, Mustoja - Toomas Lepp-Wiikmann (1894) [ATU 653].)

Ka kolmandas loos on nimekasutusega samamoodi kui algul on jutustajal juttu üldiselt kolmest vennast, siis loo lõpuosas saab neist üks peategelane - nime. Jutustaja kommenteerib oma tegevust, määratledes nime Pärtel nagu muuseas. Samas jutus kannab nime ka vendade põllul nende vilja söömas käiv võõras hobune - Kottlender. ${ }^{11}$

Foto 4. Anton Rohult kirjapandud muinasjutu lõpp (ERA II 37, 478).

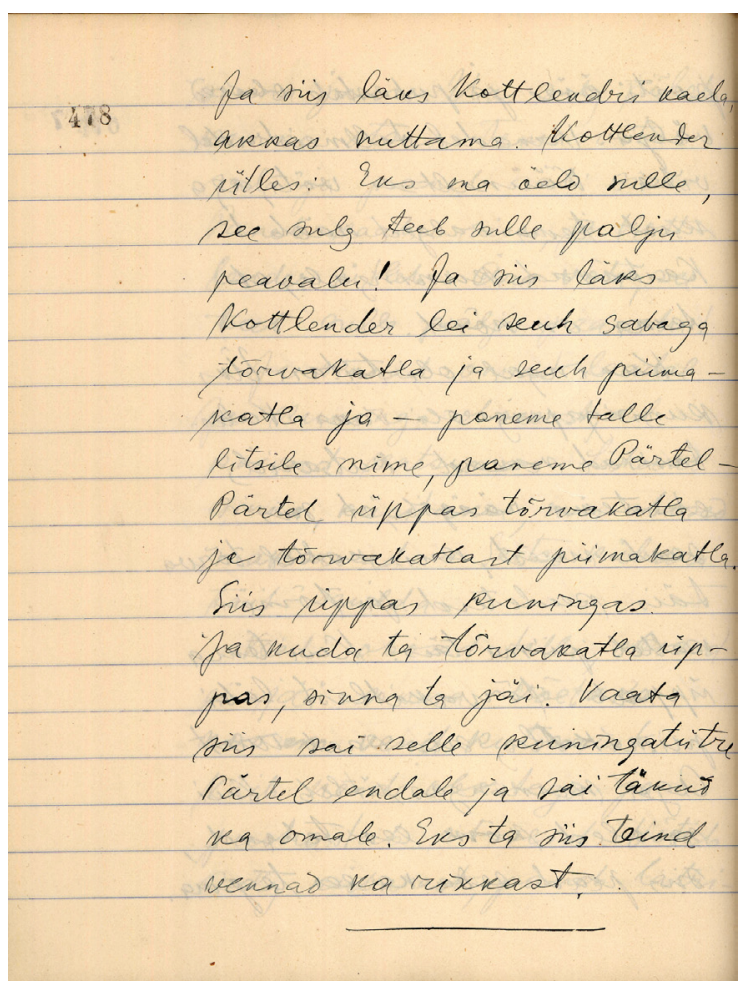


Kõige sagedamini kasutatakse nimesid tegelaspaari puhul, kus neid selle võttega vastandatakse, nende erinevust pärisnimega rõhutatakse. Näiteks on vaeslapse-peretütre tsüklisse kuuluvas jututüübis "Kelluke hiire kaelas" Ee 480E* vastandatud vaeslaps Liisi ja peretütar Triinu:

[---] Onnetuseks suri ema ära ja jättas Liisi vaiseks lapseks. Varsti perast seda vottas isa toise naise, ja ninda sai Liisi uue ema. Uuel emal oli ka tüttar, nimega Triinu. Triinu oli inetu, tige ja uhke. Uus ema aga oli oige tige Liisi vasta ja pani täda keiki raskesi töösi tegema. Ka Triinu kiusas Liisida igamoodi, ja ei rääkind tämaga ilmaski hüvaste. Nü̈̈d oli Liisil oige vilets elo. Iga päivä sai täma voora ema kääst soimada ja peksa. Et Liisi ilusam oli kui Triinu, selleperast akkas vooras ema täda veel enam vihkama. [---] (H II 36, 569/70 (27) < Vaivara khk - Marie Piik (1893?) [Ee 480E*].)

Paarikaupa on Virumaal muinasjuttudes lugudesse seatud näiteks tegelased vennad Ants ja Mart (Viru-Jaagupi), Hans ja Peeter (Kadrina khk), Ants ja Mats (Haljala khk), Silgu Samel ja Kördi Teno (koos isa Norsi Villemiga, Vaivara khk), sõbrad Jüts ja Mats (Haljala khk). Üldteatud vastandavast jututüübist “Tänulikud loomad" (ATU 554, argiteadmises tuntud ka Juhan Kunderi vastava muinasjutu pealkirja "Suur Peeter ja Väike Peeter" järgi) esinevad lisaks Suurele ja Veikesele Peetrile (3 varianti: kaks Kadrina khk, üks Vaivara khk) veel Veike Ants ja Suur Ants (Lüganuse khk), veike Jaan ja suur Jaan (Haljala khk).

Kuigi tavaliselt on Virumaa muinasjuttudes vastandatud kaht nimega jututegelast, siis mõnedel juhtudel on eristatud ka kolme. Juba Knüpfferi ümberkirjutuses Glanströmilt on tegelasnimedega variant, mis algab peale kolme venna sünniga - "3 vennaksed olnud, üks olnud Hans, keige vannem, teine olnud Maddis, kolmas olnud Tilbi nilbikenne" (EKÜ, F 232 a1, 332/7 (274) $<$ Kadrina khk < Järva-Jaani khk - A. F. J. Knüpffer < C. J. Glanström (enne 1825) [ATU $665+301+302]$ ).

Siinkohal olgu ära parandatud minu poolt varasemalt sõnastatud väide, milles määratlesin mainitud variandi kuuluvaks jututüüpi “Tänulikud loomad” (ATU 554, Järv 2005c: 549). Kuigi lugu on selle jututüübiga pisut sarnane ning kolm (nimeta) venda mitmetes Virumaa ATU 554 variantides ka esinevad, ${ }^{12}$ kuulub kõnesolev Glanströmi variant pigem kontaminatsiooni jututüüpidest "Vennad vanapagana juures" ning "Poiss varastab kuradi varandust" (ATU 327B + 328). Endiselt saab aga öelda: Eesti traditsioonis on nn Suure ja Väikse Peetri lugudes varem olnud tegu nimeta kangelastega, kes alles hiljem on endale saanud nimed, osalt ilmselt just Kunderi versioonist (Kunder 2008: 26.html) ajendatuna. 
Foto 5. A. F. J. Knüpfferi poolt C. J. Glanströmilt ümberkirjutatud muinasjutu algus (EKÜ, $f 232$ a1, 332).

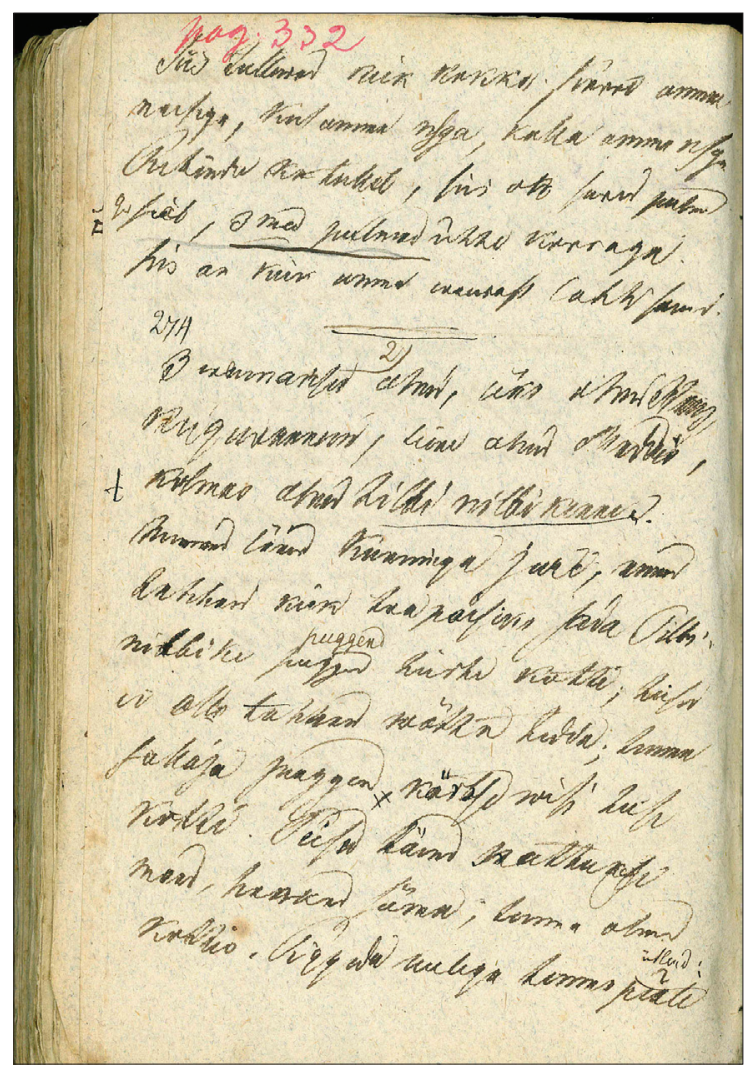

Võõrapäraseid nimesid muinasjutus kohandatakse - siingi toimib "miljöömorfoloogiline kohandumine". Sellest, kui kaugele võib minna mõne nime mugandumine, annavad tunnistust muinasjuttude väga huvitavad arendused. A. K. Kivi on kirja pannud variandi tuntud jututüübist "Seesam, lahti tee" (Ee 676), mis kannab pealkirja "Musta papa ja halli papa", ja kus tunnuslik võõrnimi AliBaba on suisa eestikeelseks seatud:

[---] Halli papa vasta: "Miks ma kurb ei peaks olema? Olen ju vaene nagu kiriku rott! Vend, kellel küll raha ja vara on, ei anna mulle raasugi, et küll teist palunud olen."

Vanamees võtnud halli papa käest kinni ja viinud ta metsa ühe koopa juure.

Koopa juures ütelnud vanamees: "Seesam, seesam, see lahti tee."

Koopa uks läinud kohe, nende sõnade peale lahti, ja vanamees viinud halli papa koopasse. [---] (E 35030/1 (2) < Kadrina khk, Tõdva-Kõnnu Joh. Schneider < Marie Reinmann (1897) [ATU 676].) 
Tüüpilisena üleüldisele muinasjututraditsioonile on kasutatud omapärast nime muinasjutu ja muistendi piirialale kuuluvas jutusüžees "Abistaja nimi” (ATU 500). Tegu on rahvusvaheliselt tuntud muinasjutuga, kus nõiduslikule abistajale on aina antud kõikvõimalikke eriskummalisi nimesid. Virumaal on kasutatud näiteks nimekujusid Ruuben Tilts, Ruuben Tiltsen, Ruupentiltsen või Rumm-Teltsa. Nime Tebärpits kannab Väike-Maarjast pärit lühikeses muistendipärases üleskirjutuses deemonlik kangelane, kes kuuleb konkreetses kohas - Ebavere mäel:

[---] Üks vanake tee peal ütles naisele: "Mine homiku vara Ebavere mäe peale ja vaata ida poole.”

Naine läks ka sinna ja nägi oma kodukäiad tansimas ja laulmas:

"Ah kui hüvä [peal: hea - R. J],

Et keegi ei tüva [peal: tea - R. J.],

Et mu nimi on Tebärpits.”

Naine oli ülirõõmus, et nime teada sai ja ütles seda, kui kodu käia pärima tuli, naine ei näind ilmaski enam kodu käiad. (H II 12, 722/3 (60) < Väike-Maarja khk - Karl Voldemar Lurich [vrd ATU 500].)

Üsna omaloomingulise väljaarendatud moega uuemas selle jututüübi tekstis on seostatud süžee tuttavasse miljöösse paigutatud kuningaga ("Arukülas olnud omal ajal kuningas...”). Äraarvatav tegelane on siin hoopis nimega Trampjalg.

[---] Ei nad tea, mis minu nimi!

Hoopis pole nipitiri,

Vaid mu salanimeke

See on, see on kena, kaunis

Trampjalg. [---]

(RKM II 379, 412 (16) < Viru-Jaagupi, Aruküla - Madis Oviir < Elfriede Strohmann, u. 80 a (1985).)

Jututüübis "Hans ja Grete" on muinasjutusüžee ja -tegelased seostatud nii konkreetse koha kui ka isikuga - nii seisab üleskirjutaja poolt tema emalt üles kirjutatud loo alguses:

Rootsi sõja ajal olnud palju inimesi metsades sõja eest pelgus, ni olnud ka Haljala kihelkonas Pehka küla juures metsas, palju inimesi pelgus, kus ka minu ema ema suur ema nimega Ann olnud. [---] (E 35213 (1) < Haljala khk - Aleksander Klaas < Mari Klaas (1897) [ATU 327A + 1121].)

Muinasjutuks "Surnupealuu" (ATU 470A) on klassifitseeritud süžee, mis oma lühiduse tõttu on lähedane muistendižanrile. Ka selle ühes variandis on tegevus seostatud kohaga. Siinkohal on esitatud loo tervikvariant: 
1000 aastat.

Keski löönd jalaga Haljala kirik’ajal pealuud. See oli aga ööld: “Ara löö ühtigi! Tule parem vaata missugune elu minul on,” ja lähend ees kiriku alle õhta poolt, kus savega kinni müüritud ukse koht on. Säält olid lahend teise ilma. Teises ilmas oli aga nii hea ja aeg nii läks nii ruttu, et 1000 aastat oli teises ilmas, nagu siin üks pääv. Kui mees tagasi saand ei ole ta enam kedagi tutavaid leidand, ise värisend ja vabisend vanusega. Kui ta teada sai kui vana ta on, surnud ta ära. (ERA II 153, 23 (11) < Haljala khk - Hermann Länts (1937) [ATU 470].)

Samamoodi on muistendižanrile lähedane muinasjutt "Surm pudelis" (ATU 331), mis algab lokaliseeringuga "Vanal, hallil ajal oli siin Venevere vallas, üks taluperemees..." (EKS 37, 33 (13) < Simuna khk - H. Kanketer < Gustav Mägi (1906)). Selle, juba kogumiku “Tuhat üks ööd” tõlgetest tuntud süžee puhul on seotus kohanimedega esil ka teiste Eesti piirkondade variantides, mis kinnitab selle teatud mõttes muistendlikke jooni). Teine sarnane lugu tüübist "Sepp ja kurat" (ATU 330) algab nii: "Vanal ajal õli Kahula külas eland üks sep. Ja sie õlla õld jällä hirmus kuri mies"13 - või siis on seostatud Virumaaga "Ennemuistsel ajal elas kuskil külas Virumaal üks sepp, kes oma ametit väga ästi osanud [---]"14.

Kuna ka loomamuinasjutud on sageli muistendlikud, pole ime, et lokaliseerimist esineb mõnigi kord ka Virumaa loomajuttudes - näiteks loos, mis jutustab jäneste plaanist maalt välja rännata (jututüüp "Kartlikum kui jänes", ATU 70). Selles ennekõike Lääne-Euroopas levinud loos (vt Kippar 1999b: 276) on Eesti variantides jäneste rändesihiks tihti Saksamaa. Virumaa ühes tüübile lähedases variandis asuvad nad teele ja kohtavad Lasnamäel karu:

Miks jänesel mokk lõhki?

Kui karu oli lasknud Lasnamäest alla, ja jäi ilma sabata, naernud selle üle vana aavikuisand - jänes, ja veel nii, et kohe moka lõhki. Sellest ajast peale ongi kõikidel jänestel, kui sellel esimese järeltulijatel, mokad lõhki. (ERA II 131, 103/4 (120) < Viru-Jaagupi khk, Roela v - Leida Böckler $<$ Emma Terras, snd 1924 (1936) [vrd ATU 70].)

Seostamist kohaliku piirkonnaga esineb samamoodi muinasjututüübis "Kalapüük sabaga" (ATU 2), millele on lisandunud vana jahimehe Mihkel Aadva jutus etioloogiline selgitus, miks karu saba lühike on:

Karul on saba sellepärast lühike, et läind kala püüdma talvel vette ja rebane old see suur õpetaja ja ütles, et kui sa tunned, et on raske, siis oota veel - et on veel raskem. Karu siis ootas hoolega kohe, niikaua kui tulid perenaised vett tooma ja teda ajama sealt. Aga karul saba kõik jääs vee 
sees, ei saa kätte kudagi, ennekui tükk otsast ära. See pidi olema Peipsi järve peal see lugu. Mõni kutsub Mustvee järv. Peipsi on ka kaarti peal. (RKM II 251, 167 (42) < Rakvere khk, Vetiku k - Mall Proodel (Hiiemäe) $<$ Mihkel Aadva, 80 a (1969) [ATU 2].)

Jutt on rahvaluulekogujale esitatud muude reaaleluliste lugude vahel.
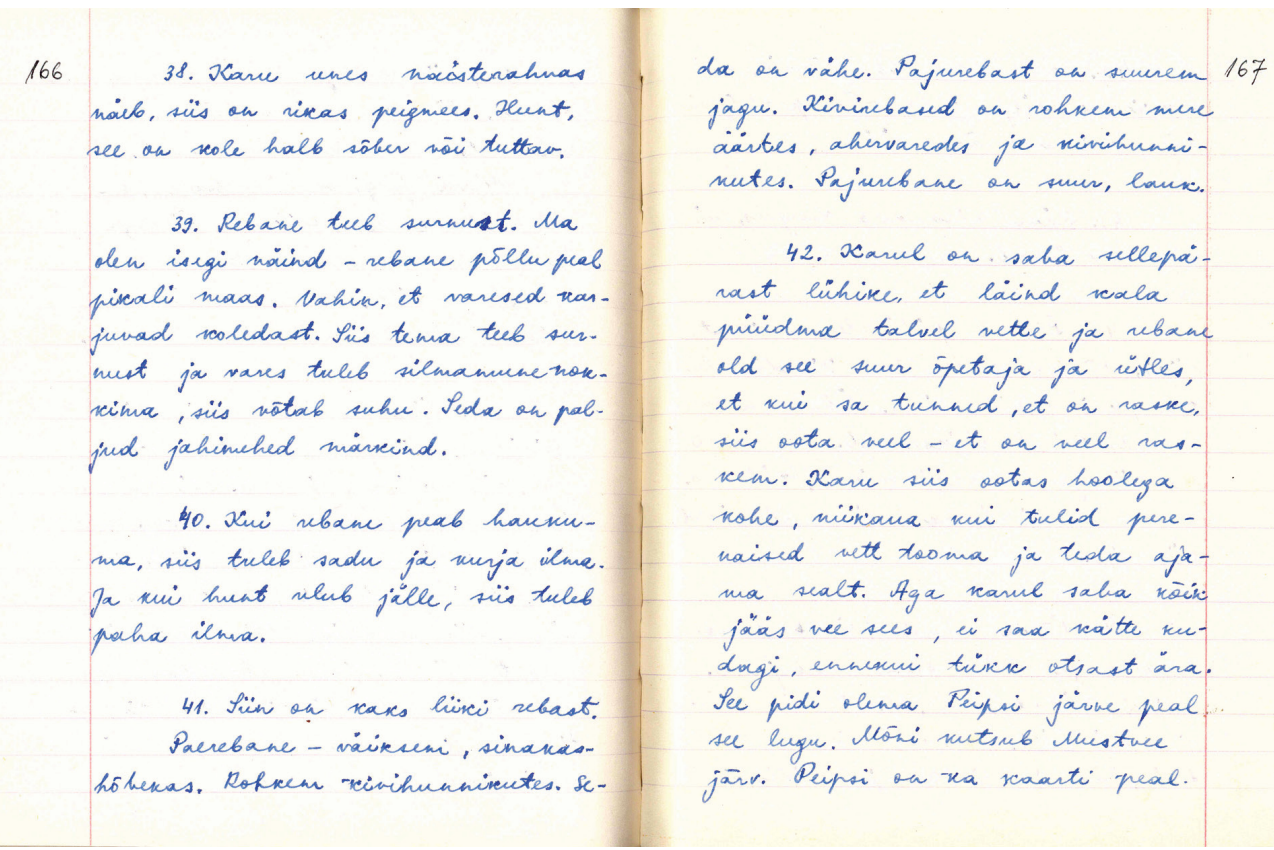

Foto 6. Mihkel Aadvalt kirjapandud loomajutte (RKM II 251, 166/7).

Narvast on kirja pandud järgmine loomamuinasjutu ning loodushäälendi piirimail olev jutt, mis on seotud Narva linnaga:

Kõik, kell maal elu igavaks läheb ehk tööd ei viitsi teha, need tullivad aga Narva. Rahva nali teab, et kui vareski maa poolt lendab, siis vaagub ta ikka: "Narva, Narva!" Kui siis tema kääst küsitakse: "Mis senna?" siis krooksub ta: "Hobune suri, hobune suri." (E 33567/8 (155) < Narva Johannes Sirdnak (1897) [ATU 243*].)

Samuti võidakse üsna ootamatult seostada kohaliku paigaga loomamuinasjuttu "Loomad põgenevad hädaohu eest" (ATU 20C). Loo jutustaja seob süžee 
Vihula valla Karula mõisaga, nii antakse rahvaetümoloogiline seletus Karula nime tekkimisele:

Usk maailma otsast / põlemisest.

Kana situs kaevu rakke pääle.

Sitt suitses. Ehmatand kana kukele:

"Maailm põleb! Maailm põleb!"

Mõlemad jooksu. Koer vastu.

"Maailm põleb! Maailm põleb!”

Kõik koos jooksu.

Niisama rebasele, hundile, karule.

Rebane vaatab üle õla tagasi-

suitsu kuskil.

Petuse eest sööb:

kukk kana ära, rebane kukke,

koer rebase, hunt koera, karu hundi.

Oli karu üksi, kahetses ennast ja kukutas

Maltsa kaldast alla.

Sealt Karula nimi.

(ERA II 153, 519 (15) > Haljala khk - Hermann Länts < Anna Taliga (1937) [ATU 20C].)

Märkimist väärib, et seda süžeed võib pidada pigem ida-euroopa traditsiooni osaks (Kippar 1999b: 277), mis taas annab kinnitust ida ja lääne traditsiooni põimumisest Virumaa muinasjutuvaramus.

Kui loomamuinasjutud ongi sageli sarnased muistendile, siis üsna ebatavaline on kohanimega seostumine imemuinasjuttude puhul. Siin on pigem tegemist konkreetsete üleskirjutajate individuaalsete arendustega. Karl Voldemar Lurich on seostanud Virumaaga loo Sarvikust ja vanapaganast, alustades muinasjuttu nii:

Sarvik kosilaseks.

Vanal ajal elas Virus, vanem Valo, selle juurde tuli Sarvik, et üht tüttart kosida, ei saand aga sugugi kaupa, kõik kolm neitsid olivad jo vahvate noorte meestega kihlatud. See tegi Sarviku meele pahaks, ta lubas kõik kolm tüdrukuid omale vija, ja pidas ka sõna. [---] (H II 12, 533 (2) < VäikeMaarja khk - Karl Voldemar Lurich (1890) [ATU 303A + 156B + 302].)

Teises Karl Voldemar Lurichi kirjapandud loos leiame rahvaetümoloogilise seletuse naaberkihelkonna Viru-Jaagupi Kulina küla kohta:

[---] Mees jõudis ühe Soome soo juurde, seal tegi ta karbi lahti, kohe seisis üks suur linn tema ees aga ilma elanikkudega. Mehel oli häda käes, 
kuda pidi ta linna jälle karpi saama. Sest murest päästis teda kull, kes sinna tuli, ta pani linna jälle karbi sisse ja ütles: "Ma arvasin kohe, et sa niisama edev ja uudishimuline oled, nagu teised inimesedki, oia ennast aga, kui sa karpi lahti teed, enne kui koju saad."

Kui mees koju jõudis, tegi ta karbi lahti, linna nimetas ta Kullilinnaks, ehk Kulinaks (nüd põle seal enam varemidki nähä), kus ta linna vanemaks sai. Linn on küll ärakadunud, nimi aga on praegugi alles, Kulina on Virumaal Jaagupi kihelkonnas. (H II 12, 564/5 (10) < VäikeMaarja khk - Karl Voldemar Lurich (1890) [ATU 222B* + 222A + 313].)

Kuigi kasutusel olev isikunimi võib olla tavaline, juhib juba isikunime kasutamine ise mõnes jutus tähelepanu sellele, et selles loos võime kohata midagi ootamatut (vrd Järv 2005c). Nii kannab peategelane nime (Hans) ka Karl Voldemar Lurichi kolmandas jutus, mis on jututüübi "Häälitsevad pealuud" (ATU 572*) ainsaks üleskirjutuseks Virumaalt (mujal Eestis on tüüp hästi tuntud, eriti Setumaal, ent tavaliselt seal isikunime ei esine). Väike-Maarja kihelkonnast pärit jutus korjab kangelane teelt üles esmalt esialgu haukuvad koerapead ja iseraiuvad kirved, ent seejärel edasises - ebatavalises - tegevuskäigus leiab ta kaks laulvat kullerkuppu(!). Näitena eripärasest süžeearendusest on see lugu avaldatud ka antoloogias "Eesti muinasjutud" (EMj I:2 2014, nr 237). Viimaks jõuab kangelane Hans kõigi leitud asjadega "Viru linna" ja saab loo lõpuosas Viru valitsejaks:

[---] Õhtuks päesis Hans metsas välla ja läks Viru linna, kust ta süia sai. Seal öeldi talle, et kuningas oma tüttre sellele naiseks lubab, kes tüttre naerma paneb, kuninga tüttar põle enne veel naerd. Hans läks kohe kuninga juurde ja üttles et ta iga üht naerda paneb. Kuningas ei taht seda uskuda, kutsus teda siisgi tuppa, kus tema tüttar istus ja üttles Hansule: "Kui sa minu tüttart naerma paned, võttan ma sind väimeheks, kui sa aga seda ei saa, siis saad ühe hea nahatäie."

Hans ei vastand sõnadki, võttis koera pead kottist välla, pani neid põrandalle, kohe akkasivad nad aukuma ja kargama, kuninga tüttre suu läks jo kõveraks.

Nü̈̈d võttis Hans kerveid välla, kes raiuma akkasivad; jo paistsivad kuninga tüttre hambad.

Kui Hans aga lauljad lilled välla võttis, naeris imeilus neitsi täie häelega.

Rõõmuga võttis kuningas Hantsu oma väimeheks.

Nii sai siis veike Hans Viru valitsejaks. (H III 2, 765/6 (4) < VäikeMaarja khk - Karl Voldemar Lurich (1888) [ATU 572*].) 
Foto 7. K. V. Lurichi saadetud muinasjutu lõpp (H III 2, 766).

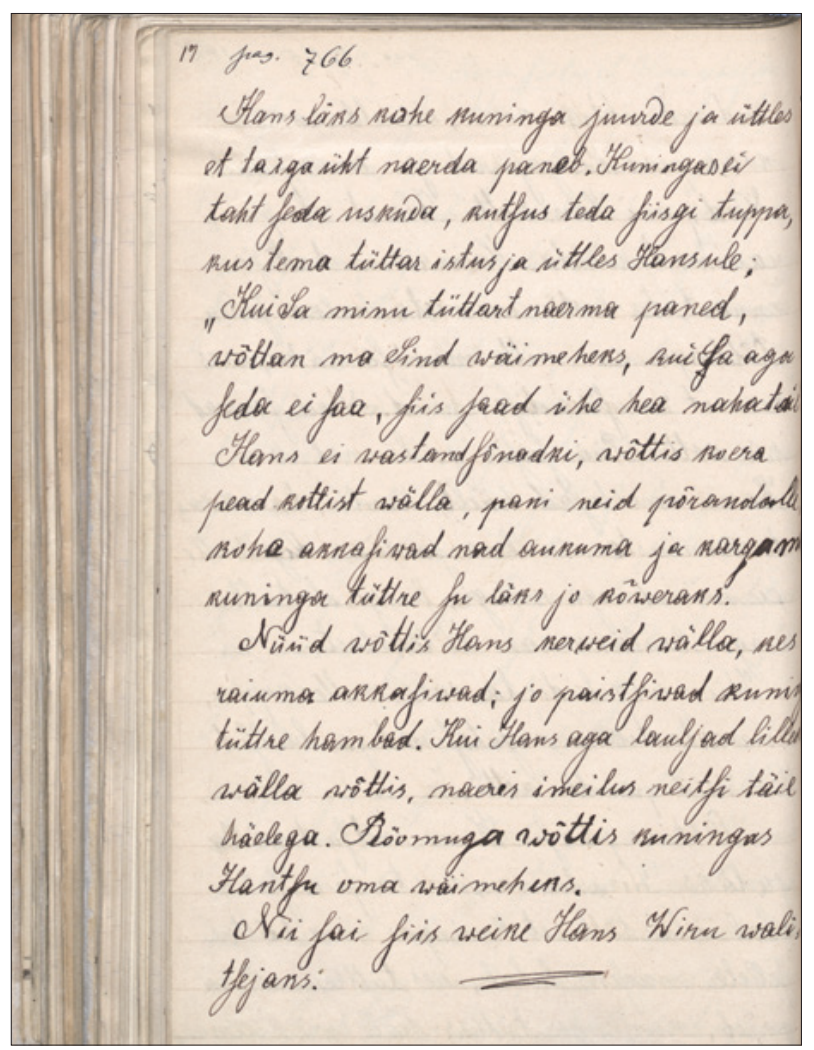

Tõsi, sellises seostamises ei ole kirjandusliku traditsiooni puhul midagi ebatavalist, nii viitab Alutagusele näiteks juttudes "Tontla mets" ning "Puulane ja tohtlane" ka Kreutzwald (vt Annist 1966: 314). Samalaadset koha- ja isikunimede küllusliku kasutamise strateegiat on kasutatud ka tänapäeval Virumaaga seotud muistendlikes autorimuinasjuttudes, näiteks raamatus "Vana Hanni pajatused. Eesti legendid ja Ida-Virumaa muinasjutud" (Kont 2016), kus eri juttudes on mainitud Soome lahte, Toila jõge, Valaste juga, tegelastena esinevad vennad Günter ja Otto, näkineiu Lelli, noormees Armas, tütar Aurelia jmt.

Seega võime tõdeda, et Virumaa muinasjututraditsioonis on oma koha leidnud mõned ebatraditsioonilised ning nimerohked arendused. Ulatuslikumat statistikat tegemata tundub tõesti, et nii isiku- kui kohanimede poolest on Virumaa suhteliselt nimerikas, ent selle täpne väljaselgitamine jäägu tehtavaks tulevikuvaatlustes. 
Lõpetan vaatluse ühe Mäetaguse vallast üles kirjutatud looma(muinas)jutuga, tüüpi "Hunt (karu) sureb hirmust" (Kippar 169L*, ATU 169*) kuuluva lühikese looga:

Karu käind kaeras. Mies tuld pimedas mõisast tüelt ja vahtind, et teisepere siga minu kaerasaatude kallal. Läind salamiste saadu tagant ja virutand leivamärsiga. Old karu, üppand paar samu ja ehmatand enese surnust. (ERA II 166, 365/6 (6) < Iisaku khk, Mäetaguse v, Vaabu k - Armilda Hallik < Konstantin Kiiver, snd 1875 (1937) [Kippar 169L*].)

Nii näitab muinasjutt Virumaa ja teistelegi inimesele, et kardetavatest saab ikka võitu, olgu vastaseks muidu kardetud metsloom või mõni koletu jube elajas.

Vaatamata mõnedele idapoolsetele tunnusjoontele, mis iseäranis ilmnevad just neljas Ida-Virumaa kihelkonnas, kuulub Virumaa muinasjututraditsioon üldhinnangus Põhja-Eesti rahvajutuvarasse. Muinasjuttudes nimede kasutamise strateegiate poolest on Virumaa jutustajad olnud sarnased muule Eestile. Kuigi kohanimesid tundub esinevat Virumaa muinasjuttudes mõnevõrra rohkem kui Eestis keskmiselt, on väga eripärased arendused selles vallas tihti tingitud ennekõike konkreetsete kirjapanijate stiilist.

\section{Kommentaarid}

1 Artikli valmimist on toetanud Haridus- ja Teadusministeerium (projektid IUT 22-4 ja IUT 2-43) ning Euroopa Liit Euroopa Regionaaluuringute Fondi kaudu (Eestiuuringute Tippkeskus).

${ }^{2}$ H II 34, 428 (2) < Viru-Nigula khk, Laheküla, Suurekivi t - Hans Lohk < Leenu Uudam, 67 a (1892) [ATU $313+400$ ].

3 E 46077 < Viru-Nigula khk - Gustav Johann Jurjev-Kallus (1907) [ATU 750A].

4 Schlegeli saksakeelses tekstis on värsside juures ka eestikeelne algvariant:

"Tulle koio lapse-eide, / tulle lasta lakkutama, / pissikesta immetama. / Lapse immeb tohhinissi, / lakkub vaske vardaaida. / Lapse silmad torgitakse / tohhisilla, torbikulla / vaskisilla, vardaalla" (EKÜ, f 232 d, 57/8).

5 H II 34, 436/7 (7) < Viru-Nigula khk, Laheküla, Suurekivi t - Hans Lohk < Leenu Uudam, 67 a (1892) [ATU 403C + 409].

${ }^{6}$ Ka sellel tekstil on olemas põnev paralleelkirjapanek, mida käesolevas artiklis pikemalt käsitleda ei saa. Samal aastal samalt jutustajalt Rosenstrauchi poolt koos Peeter Pennaga üles kirjutatud variandis (EÜS VII 2121/34 (324) < Väike-Maarja khk, Porkuni v, Piisupi k - Karl Voldemar Rosenstrauch ja Peeter Penna $<$ Hans Aberthal, 50 a (1910)) varieerub tekst märgatavalt, muuhulgas on jutustaja (või kirjapanijad?) seal asendanud ka tegelasi ning nende omavahelisi positsioone.

7 Tüübikataloogi kümnes variant [Hlj 4] ERA II 198, 83/4 (84) kuulub pigem teise jututüüpi $166 \mathrm{~A}^{*} 2$. 
8 RKM II 230, 402/5 (13) < Lüganuse khk, Küttejõu as < Loome k - Aino Källo < Peeter Lepik, snd 1903, Püssi al (1967) [Kippar 179D].

9 Just loo lõppu tavatsevad jutustajad põimida endaga seotud humoorikaid detaile. Nii näiteks jutuvestja rätsep Anton Roht on ühe tuntud, üldantoloogias "Eesti muinasjutud" (1967) oleva imemuinasjutu "Kolm röövitud kuningatütart" (ATU 301) lõpul kasutanud reaalsusega seostatud allusiooni:

"[...] Ja siis õli sellil rammu ja kullisulg külles ja siis akkasid lendu. Ja vei kuningatütred üle mere. Ja kinkis siis kuningale kaks tütart tagasi ja palus siis omale see noorem tütar. Ja siis sai kuninga väimehest ja kuningriigi perijast.

Ja see on selge, et pulmi oli tublist. Minagi tantsisin, et jalg jäi vigasest." (ERA II 37, 449/50 (14) < Jõhvi khk, Voka v, Konju k - R. Põldmäe < Anton Roht (1931) [ATU 301].)

Üleskirjutaja Rudolf Põldmäe on lisanud kommentaari: "Jutustaja oligi vigase jalaga." Nõnda on jutuvestja äraspidi huumorit kasutades konkretiseerinud fiktiivse elemendi.

${ }^{10}$ E 81040 (5) < Iisaku khk, Mäetaguse v, Uhe k - H. Juulmann (Jõulmaa) < Heleene Martin, 58 a (1932) [ATU 312D + vrd 480 + vrd 311].

11 ERA II 37, 474/8 (17) < Jõhvi khk, Voka k < Konju k - Rudolf Põldmäe < Anton Roht (1931) [ATU 531].

${ }^{12}$ Vrd näiteks Jõhvi kihelkonnast Anton Rohult üleskirjutatud paralleelvariandi algus: "Kolm kuningapoiga läksid reisima. Akkasid esimest ommikust sööma, ja tuleb üks sipelgas sinna nende juure. Vanem vend tahab lüüa sipelga surnust, aga noorem vend annab temale leivaraasukesi ja ütleb: "Las loom elab!" Sipelgas läheb välja ja ütleb: "Kui ädaaig on, siis üüa mind appi."” [---] (ERA II 37, 450/1 (15) < Jõhvi khk, Voka v, Konju k - Rudolf Põldmäe < Anton Roht, 81 a (1931) [ATU 554].).

${ }^{13}$ ERA II 268, 406/14 (2) < Jõhvi khk, Kohtla k - Endel Mets < Mariie Vihmann, 80 a (1939) [ATU $330+\operatorname{vrd} 313 \mathrm{~A}]$.

${ }^{14}$ H II 11, 690/6 (5) < Väike-Maarja khk - Konrad Roost < Jaan Holtzmann (1889) [ATU 330].

\section{Arhiiviallikad}

\section{Eesti Kirjandusmuuseumi Eesti Rahvaluule Arhiivis (järjestatud algusdaatumite järgi)}

EKÜ - Eestimaa Kirjandusliku Ühingu rahvaluulekogu (19. saj algus - 1890)

H - J. Hurda rahvaluulekogu (1860-1906)

EKS - Eesti Kirjanduse Seltsi rahvaluulekogu (1872-1924)

EÜS - Eesti Üliõpilaste Seltsi rahvaluulekogu (1875-1917)

E - M. J. Eiseni rahvaluulekogu (1880-1934)

ERM - Eesti Rahva Muuseumi rahvaluulekogu (1915-1925)

E, StK - M. J. Eiseni stipendiaatide rahvaluulekogu (1921-1927)

ERA - Eesti Rahvaluule Arhiivi rahvaluulekogu (1927-1944) 
RKM - Eesti TA Fr. R. Kreutzwaldi nim. Riikliku Kirjandusmuuseumi rahvaluule osakonna rahvaluulekogu (1945-1994)

Arhiivitekstid on esitatud minimaalselt redigeerituna, parandatud on interpunktsiooni.

\section{Kirjandus}

$\mathrm{Aa}=$ Aarne, Antti 1918. Estnische Märchen- und Sagenvarianten: Verzeichnis der zu den Hurt'schen Handschriftssammlungen gehörenden Aufzeichnungen mit der Unterstützung der Finnisch-ugrischen Gesellschaft. FF Communications 25. Hamina: Suomalainen Tiedeakatemia.

Anderson, Walter 1933. J. H. Rosenplänteri eesti muinasjutud. Suomi V: 16. Helsinki: Suomalisen Kirjallisuuden Seura, lk 15-37.

Annist, August 1966. Friedrich Reinhold Kreutzwaldi muinasjuttude algupära ja kunstiline laad. Tallinn: Eesti Raamat.

Annist, August 2005. Friedrich Reinhold Kreutzwaldi “Kalevipoeg”. Toimetanud Ülo Tedre. Tallinn: Eesti Keele Sihtasutus.

ATU = Uther, Hans-Jörg 2004. The Types of International Folktales. A Classification and Bibliography. Based on the System of Antti Aarne and Stith Thompson. FF Communications 284-286. Helsinki: Academia Scientiarum Fennica.

EMj 1967 = Mälk, Vaina \& Sarv, Ingrid \& Viidalepp, Richard (koost); Viidalepp, Richard (toim). Eesti muinasjutud. Tallinn: Eesti NSV TA Keele ja Kirjanduse Instituut.

EMj I:1 2009 = Järv, Risto \& Kaasik, Mairi \& Toomeos-Orglaan, Kärri (koost ja toim). Eesti muinasjutud I:1. Imemuinasjutud. Monumenta Estoniae Antiquae V. Tartu: Eesti Kirjandusmuuseumi Teaduskirjastus.

EMj I:2 2014 = Järv, Risto \& Kaasik, Mairi \& Toomeos-Orglaan, Kärri (koost ja toim); Annom, Inge (toim). Eesti muinasjutud I:2. Imemuinasjutud. Monumenta Estoniae Antiquae V. Tartu: Eesti Kirjandusmuuseumi Teaduskirjastus.

ERk 2017 = Hiiemäe, Mall \& Lätt, Selma. Eesti rahvakalender. Tartu: EKM Teaduskirjastus (http://www.folklore.ee/erk/ - 17. juuni 2017).

Hiiemäe, Mall 2006. Rahvajutud. Saaber, Kalju (koost). Koguteos Virumaa. Rakvere: Lääne-Viru Maavalitsus, Ida-Viru Maavalitsus, lk 428-433.

Hiiemäe, Mall 2010. Pühad ja argised ajad rahvakalendris. Tallinn: Varrak.

HVM I = Laugaste, Eduard \& Normann, Erna 1959. Muistendid Kalevipojast. Eesti muistendid. Hiiu- ja vägilasmuistendid I. Monumenta Estoniae Antiquae II. Tallinn: Eesti Riiklik Kirjastus.

Holbek, Bengt 1987. Interpretation of Fairy Tales: Danish Folklore in European Perspective. Folklore Fellows Communications 239. Helsinki: Suomalainen Tiedeakatemia.

Järv, Risto 1999. Vale-Jüri kiusatus. Valekangelasest "Lohetapja" (AT 300) põhjal. Hiiemäe, Mall \& Oras, Janika \& Tamm, Kadri (toim). Lohetapja. Pro Folkloristica VI. Tartu: Eesti Kirjandusmuuseum, lk 52-69. 
Järv, Risto 2001. Eesti imemuinasjuttude kangelaste, jutustajate ja kogujate soost. Hiiemäe, Mall \& Labi, Kanni (toim). Klaasmäel. Pro Folkloristica VIII. Tartu: Eesti Kirjandusmuuseum, lk 28-44.

Järv, Risto 2002. Ehe ja ehitud. Mõnest autentsusprobleemist 19. sajandi muinasjutukirjapanekutes. Hiiemäe, Mall \& Labi, Kanni (toim). Kogumisest uurimiseni. Artikleid Eesti Rahvaluule Arhiivi 75. aastapäevaks. Eesti Rahvaluule Arhiivi toimetused 20. Tartu: Eesti Kirjandusmuuseum, lk 157-180.

Järv, Risto 2005a. Eesti imemuinasjuttude tekstid ja tekstuur. Arhiivikeskne vaatlus. Tartu: Tartu Ülikooli Kirjastus.

Järv, Risto 2005b. Muinasjutt. Metsvahi, Merili \& Valk, Ülo (koost). Regivärsist netinaljadeni. Sissejuhatus rahvaluulesse. Tallinn: Koolibri.

Järv, Risto 2005c. Sehvtjeviiten ja seitse tõdemust. Isikunimedest muinasjuttudes. Keel ja Kirjandus, nr 6, lk 442-454; nr 7, lk 549-557.

Kippar, Pille 1985. Varese naisevõtt (AT 243*). Rahvasuust kirjapanekuni. Uurimusi rahvaluule proosaloomingust ja kogumisloost. Emakeele Seltsi toimetised 17. Tallinn: Eesti NSV Teaduste Akadeemia, lk. 83-100.

Kippar, Pille 1986. Estnische Tiermärchen. Typen- und Variantenverzeichnis. Folklore Fellows Communications 237. Helsinki: Suomalainen Tiedeakatemia.

Kippar, Pille 1989. Eesti loomamuinasjuttude tegelastest. Hiiemäe, Mall (toim). Paar sammukest eesti kirjanduse uurimise teed. Uurimusi XII. Jakob Hurda 150. sünniaastapäevaks. Tallinn: Eesti Raamat, lk 148-157.

Kippar, Pille 1999a [1997]. Loomad, linnud, putukad: Eesti loomamuinasjutte. Tartu: Eesti Keele Instituut USN (http://www.folklore.ee/pubte/muina/loomad/- 17. juuni 2017).

Kippar, Pille 1999b. Läänemeresoome ja balti piirkond kui kontaktiväli lääne ja ida vahel. Pajusalu, Karl \& Tender, Tõnu (toim). Õdagumeresoomõ veeremaaq / Läänemeresoome perifeeriad. Võru Instituudi toimetised / Võro Instituudi Toimõtise' 6. Võru: Võro Instituut, lk 275-279.

Kont, Eduard 2016. Vana Hanni pajatused. Eesti legendid ja Ida-Virumaa muinasjutud. Lastele ja täiskasvanutele. [Kohtla-Järve: E. Kont.]

Kreutzwald, Friedrich Reinhold 1953 [1866]. Eesti rahva ennemuistsed jutud. Friedrich Reinhold Kreutzwald. Teosed. Tallinn: Eesti Riiklik Kirjastus.

Kunder, Juhan 2008 [1885]. Eesti muinasjutud. Kommenteeritud väljaanne (http://www. folklore.ee/UTfolkl/mj/kunder/ - 17. juuni 2017).

Metsvahi, Merili 2010. "Naine libahundiks" (AT 409) eesti jutupärimuses. Keel ja Kirjandus, nr 8-9, lk 611-627.

Mälk, Vaina 1963. Eesti Kirjameeste Seltsi osa eesti folkloristika arengus. Keele ja Kirjanduse Instituudi uurimused 7. Tallinn: Eesti Riiklik Kirjastus.

Salve, Kristi 1987. Eesti loomamuinasjuttude kataloogist. Keel ja Kirjandus 12, lk 749_ 753. 
Salve, Kristi 2013 [1992]. "Lorijal lõuvad, kuuljal kõrvad.” Ida-Virumaa rahvajuttudest. Rüütel, Ingrid (koost ja toim). Ida-Virumaa rahvakultuurist. Teine, parandatud ja täiendatud trükk. Rakvere-Tartu: Viru Instituut, lk 127-155.

Toomeos-Orglaan, Kärri 2005. Vanimatest imemuinasjuttude kirjapanekutest, nende koopiatest ja trükiversioonidest. Hiiemäe, Mall \& Labi, Kanni (toim). Aega otsimas. Pro Folkloristica XII. Tartu: Eesti Kirjandusmuuseum, lk 151-164.

Viidalepp, Richard 2004 [1965]. Eesti rahvajuttude laadist, funktsioonist ja jutustajatest. Sator 4. Tartu: Eesti Kirjandusmuuseumi rahvausundi töörühm (www.folklore.ee/rl/ pubte/ee/sator/sator4/sator4.pdf - 17. juuni 2017).

Risto Järv - Eesti Kirjandusmuuseumi Eesti Rahvaluule Arhiivi juhataja, Tartu Ülikooli eesti ja võrdleva rahvaluule osakonna dotsent.

risto@folklore.ee

\section{Summary}

\section{Fairy tales from Virumaa: On the border of truth and reality}

Risto Järv

Keywords: fairy tale, legend, place narrative, Virumaa

One tenth of the fairy tales in the Estonian Folklore Archives have been collected in Virumaa. The article gives an overview of the fairy tale types most widely spread in Virumaa: wondertales ATU 300, 301, 313, 327A, 403C, 409, 480, 650B, and animal tales ATU 117, 169*, 243. Some tales of magic less known elsewhere in Estonia (ATU 312D, 326, 650B) are inherent in Virumaa. The article dwells upon fairy tales including anthroponyms, which are rather exceptional among fairy tales, and also fairy tales that are related to concrete places in Virumaa.

In spite of some eastern features especially prominent in four parishes of Ida(East)Viru County, Virumaa fairy tale tradition generally belongs to northern Estonian fairy tale repository. By their strategies of name-using in fairy tales, Virumaa narrators have been similar to the ones elsewhere in Estonia. Although Virumaa fairy tales seem to include more place names than in Estonia on average, the most peculiar developments in this sphere often result, above all, from the style of concrete collectors.

Risto Järv is Head of the Estonian Folklore Archives at the Estonian Literary Museum, and Associate Professor of the Department of Estonian and Comparative Folklore at the University of Tartu.

risto@folklore.ee 